\title{
Transfer Of Knowledge Through The Lens Of rganizational Culture: A Literature Review
}

\author{
Shabana Gul \\ Assistant Professor, Institute of Management Sciences, Peshawar \\ shabana.gul@imsciences.edu.pk \\ Dr. Waseef Jamal \\ Associate Professor, Institute of Management Sciences, Peshawar \\ waseef.jamal@imsciences.edu.pk
}

\author{
Alam Sher \\ Institute of Management Sciences, Peshawar \\ alamsher136@gmail.com
}

\begin{abstract}
:
This study aims to summarize the possible relationship between the transfer of knowledge and organizational culture and highlight the empirical relevance between them. For this purpose, a literature review of 169 articles (both qualitative and quantitative studies) has been conducted that have attempted to provide evidence of their relationship. Future empirical research suggestions for understanding the relationship between organizational culture and transfer of knowledge are also provided
\end{abstract}

Keywords: Organizational Culture, Transfer of Knowledge, Literature Review, HEI

\section{Introduction}

In today's dynamic environment Knowledge is considered as the lifeblood of organizations and has been established as an important element in their survival. Thus, managing knowledge is equivalently important as managing other assets of an organization. Organizations are totally dependent on knowledge both as a critical success factor and resource for attaining sustained competitive advantage (Nahapiet\&Ghoshal, 1998). Effective knowledge management in organizations has resulted in positive outcomes in shape of higher productivity, improved performance and increase in innovative capabilities and thus has created a substantial interest in the field of knowledge management (Cummings, 2004; Mesmer-Magnus \&DeChurch, 2009). However, knowledge deteriorates if not managed and transferred effectively. Especially, tacit knowledge which lives in the minds of the employees and is gained over time must be transferred and shared. Long term goals can be achieved by improving the ability to create and manage knowledge assets effectively (De Long \& Fahey, 2000) however, organizations that champion transfer of knowledge within the organization (via creating and following transfer processes) enjoy the likelihood of attaining sustainable competitive advantage over a period of time (Argote \& Ingram, 2000).

Although the positive outcomes of transferring knowledge within organizations have been realized long ago (Burmeister, Wang \&Hirschi, 2019; Ilvonen, Jussila, \&KärkkäinenH 2019), the effective transfer of knowledge nevertheless faces many challenges (Stadler, 2019). Scholars agree that an organization's culture poses a big challenge to the effective transfer of knowledge (Ajmal\&Koskinen, 2008). Organizational culture is considered as pre-understood assumptions, collective communal patterns of meaning among the members of the organization and the manifestation of these assumptions (Slocum, 1995; Gundykunst\& Ting- Toomey, 1988). Although many knowledge transfer interventions (processes 
development and maturity) fail on account of organizational cultural factors as compared to technological adaptabilities, yet, very little is understood about the organizational cultural perspective of transfer of knowledge, partially because organizational culture is a complex and vague concepts with multiple perspectives and interpretations(Ajmal\&Koskinen, 2008). Given the importance of effective transfer of knowledge and the role of organizational culture on the transfer of knowledge, this article reviews prior scholarly literature on the transfer of knowledge and organizational culture to develop a theoretical framework in order to establish a relationship and make various contributions.

Firstly, systematic review of available literature is conducted to analyze the state of the available literature. Secondly, theoretical and empirical relevance between the transfer of knowledge and organizational culture. Lastly, recommendations for conducting empirical research regarding measurement of the under discussion constructs are also provided. Researchers are urged to (1) apply alternative methodologies, (2) conduct empirical research to examine the relationship between sub-covert cultures on transfer of knowledge processes, and (3) examine any probable negative relationship between organizational culture an transfer of knowledge.

This review article consists of six main sections in addition to this introduction and conclusion. The second section outlines the literature review process and search. Section three and four provide a discussion on the findings from 179 research articles which includes a brief history, definitions, types, dimensions, differentiation from similar constructs and characteristics of organizational culture, and transfer of knowledge respectively. This is followed by section five which outlines the relevance between OC and KT as well as a map of subject matters that have been published, research methods that have been used, dimensions of their studies, and their findings. Section six outline discussion ad critique on various measurement instruments used to measure OC and KT.

\section{Literature Review Process}

Prior to undertaking the literature review, the selection criteria of the study was designed as follows:

\section{Table-2.1 Studies Selection Criteria}

\begin{tabular}{|c|c|}
\hline Inclusion Criteria & Exclusion Criteria \\
\hline $\begin{array}{l}\text { - Studies that defined organizational } \\
\text { culture, its type, and characteristics } \\
\text { - Studies that defined knowledge } \\
\text { management, transfer of knowledge, } \\
\text { characteristics of transfer of } \\
\text { knowledge } \\
\text { - Studies that empirically tested the } \\
\text { relationship of organizational culture } \\
\text { and transfer of knowledge post-2000. } \\
\text { - Studies that explained the } \\
\text { measurement instruments of } \\
\text { organizational culture and transfer of } \\
\text { knowledge. }\end{array}$ & $\begin{array}{l}\text { - Studies that proved the relationship } \\
\text { between Organizational Culture and } \\
\text { Knowledge Management. } \\
\text { - Book reviews and introductory } \\
\text { papers were excluded. } \\
\text { Papers assessing the relationship } \\
\text { between Organizational culture with } \\
\text { other variables e.g. performance, } \\
\text { workplace stress, commitment, etc. } \\
\text { Empirical studies that were not in } \\
\text { English. }\end{array}$ \\
\hline
\end{tabular}

Search for studies to be included in literature review was carried following available best practices. Higher Education Commission of Pakistan's (HEC) digital library was used for locating the studies fulfilling the stated criteria. Given the limited access to search engines, it was decided to use multidisciplinary search engines limited to SAGE publications, Emerald, ELSEVIER (Science Direct), JSTOR, Springer Link, and open access journals on Google 
Scholar. Within each of the search engine following search strings within abstracts and titles were used for retrieving studies: "transfer of knowledge and organizational culture", "determinants of knowledge transfer", "relationship between organizational culture and transfer of knowledge" and "knowledge sharing and transfer of knowledge", "measurement of transfer of knowledge". In total, 161 papers were selected for the literature review, the following table provides the details of the database accessed;

Table- 2.2 Summary of the Search Process

\begin{tabular}{|l|l|}
\hline Sources & Selected Papers \\
\hline Google Scholar & 63 \\
\hline Emerald Insight & 25 \\
\hline ELSEVIER (Science Direct) & 20 \\
\hline Wiley Online Library & 14 \\
\hline SAGE Journals & 10 \\
\hline JSTOR & 8 \\
\hline Springer Link & 7 \\
\hline Taylor and Francis Online & 6 \\
\hline Proquest & 4 \\
\hline Semantic Scholar & 4 \\
\hline Total & $\mathbf{1 6 1}$ \\
\hline
\end{tabular}

Each of the downloaded studies was thoroughly read and their findings were reported as it is. For empirical studies, the details of author and study title, population \& sampling, dimensions of variables, measurement instruments, and findings were reported.

\section{Organizational Culture}

\subsection{Roots of Organizational Culture}

The term culture first appeared in the Oxford English Dictionary around 1430 AD. Culture meant cultivation. The same meaning was used until the $19^{\text {th }}$ century for referring to the high cultures of society, the context was the cultivation of manners, values, and mindset. The trend held its ground till the $20^{\text {th }}$ century, however by mid- $20^{\text {th }}$ century American Heritage English Dictionary redefined the term. The culture was now defined as "the totality of socially transmitted behavior patterns, arts, beliefs, institutions, and all other products of human work and thought." However British anthropologist Edward Tyler was the first (1871) to give a modern definition of culture i-e. "that complex whole which includes knowledge, belief, arts, morals, law, custom, and any other capabilities and habits acquired by man as a member of society.

Though the academic interest in culture and organizational culture has a long history as per anthropology and social science, for business organizations the roots of organizational culture dates back to 1979 when Pettigrew introduced anthropological concepts of "Symbolism, myths and rituals" for analyzing an organization's culture. The formal use of the word organization culture/corporate culture started when two famous books: "In Search of Excellence" by Tom Peters \& Robert Waterman (1982) and "Corporate Cultures" by Terrence Deal and Allen Kennedy (1980) were published.

\subsection{Defining Organizational Culture}

Several definitions exist of organizational culture depending on the level of analysis of organization culture i-e. individual level, group level, or organization level. Although there is no consensus on the definition yet several researchers have defined organizational culture, table 3.1 provides a summary as follows: 
Table-3.1 Definitions of Organizational Culture

\begin{tabular}{|c|c|c|}
\hline Author \& Year & Definition & Focus \\
\hline $\begin{array}{l}\text { Kroeber } \\
\text { \&Kluckhohn } \\
(1952)\end{array}$ & $\begin{array}{l}\text { Organization culture is about communicating values } \\
\text { and ideas that set up the behavior of an organization. }\end{array}$ & $\begin{array}{l}\text { Sharing and } \\
\text { communication of } \\
\text { values and ideas }\end{array}$ \\
\hline Geertz (1973) & $\begin{array}{l}\text { "Culture is the creation of meaning through which } \\
\text { human beings interpret their experiences and guide } \\
\text { their actions, while the social structure is the form } \\
\text { which action takes or the network of social } \\
\text { relationships which actually exists" (Greetz, 1973, p. } \\
\text { 145) }\end{array}$ & $\begin{array}{l}\text { The breeding } \\
\text { ground of value } \\
\text { system and social } \\
\text { interactions }\end{array}$ \\
\hline $\begin{array}{l}\text { Swartz \& } \\
\text { Jordon }(1980)\end{array}$ & $\begin{array}{l}\text { Organization culture is the product of members } \\
\text { believes and expectation that result in behavioral } \\
\text { norms. }\end{array}$ & $\begin{array}{l}\text { Collective value } \\
\text { system }\end{array}$ \\
\hline Ouchi (1981) & $\begin{array}{l}\text { It's the communication of organization symbols, } \\
\text { myths, values, believes and ceremonies. }\end{array}$ & Symbolism \\
\hline $\begin{array}{lr}\text { Deal } & \& \\
\text { Kennedy } & (1982) \\
\end{array}$ & $\begin{array}{l}\text { The way things are done in an organization makes its } \\
\text { culture. }\end{array}$ & $\begin{array}{l}\text { Provides a basis } \\
\text { for action }\end{array}$ \\
\hline Uttal (1983) & $\begin{array}{l}\text { Shared values (what is important) and beliefs (how } \\
\text { things work) that interact with an organization's } \\
\text { structures and control systems to produce behavioral } \\
\text { norms (the way we do things around here) }\end{array}$ & $\begin{array}{l}\text { Collective values } \\
\text { and norms }\end{array}$ \\
\hline $\begin{array}{l}\text { Frost et } \\
(1985)\end{array}$ & $\begin{array}{l}\text { 'Talking about organization culture seems to mean } \\
\text { talking about the importance for people of } \\
\text { symbolism - of rituals, myths, stories and legends - } \\
\text { and about the interpretation of events, ideas, and } \\
\text { experiences that are influenced and shaped by the } \\
\text { groups within which they live.'(Frost et al, } 1985 \text {, } \\
\text { p.17) }\end{array}$ & People-focused \\
\hline Adler (1986) & $\begin{array}{l}\text { (a) Organization culture is something shared by } \\
\text { everyone (b) Something that is transferred from the } \\
\text { older members to the younger ones (c) Something } \\
\text { that makes the behaviors and structures of an } \\
\text { organization. }\end{array}$ & Transference \\
\hline Denison (1990) & $\begin{array}{l}\text { Organization culture are embedded values, believes, } \\
\text { and principles that form the organization's } \\
\text { management system, practices, and behaviors. }\end{array}$ & Value system \\
\hline $\begin{array}{l}\text { Trompenaars } \\
\text { (1993) }\end{array}$ & $\begin{array}{l}\text { It's the problem-solving techniques of organization } \\
\text { members, their shared system of values and } \\
\text { meanings. }\end{array}$ & $\begin{array}{l}\text { A shared collective } \\
\text { value system }\end{array}$ \\
\hline Goffee (1996) & $\begin{array}{l}\text { Organization culture is the result of inter- } \\
\text { organization relationships. }\end{array}$ & Social Networks \\
\hline $\begin{array}{l}\text { Gareth Morgan } \\
\text { (1997) }\end{array}$ & $\begin{array}{l}\text { "The set of the set of beliefs, values, and norms, } \\
\text { together with symbols like dramatized events and } \\
\text { personalities that represent the unique character of an } \\
\text { organization, and provides the context for action in it } \\
\text { and by it." (Morgan, 1997, p.41). }\end{array}$ & $\begin{array}{l}\text { A shared collective } \\
\text { value system }\end{array}$ \\
\hline Schneider & Shared patterns of behavior and the meaning of that & Transference \\
\hline
\end{tabular}




\begin{tabular}{|c|c|c|}
\hline (1997) & behavior. & \\
\hline $\begin{array}{l}\text { Cameron \& } \\
\text { Quinn (1999) }\end{array}$ & $\begin{array}{l}\text { Organization culture is everything from values, } \\
\text { leadership styles, language, processes, and the way } \\
\text { things are seen in an organization. }\end{array}$ & Collective \\
\hline Sullivan (2001) & $\begin{array}{l}\text { It is about the complete code of living from values to } \\
\text { ideas, knowledge, behaviors, and all that they share. }\end{array}$ & $\begin{array}{l}\text { Collective and } \\
\text { comprehensive }\end{array}$ \\
\hline $\begin{array}{l}\text { Hill \& Jones } \\
(2001)\end{array}$ & $\begin{array}{l}\text { Organization culture comprises of artifacts, } \\
\text { experiences, and values of an organization. }\end{array}$ & Symbolism \\
\hline Wiesner (2002) & $\begin{array}{l}\text { It is looking at the organization from the lens of } \\
\text { values and believes. }\end{array}$ & Value System \\
\hline $\begin{array}{l}\text { Thomas } \& \\
\text { Tung (2003) }\end{array}$ & $\begin{array}{l}\text { Refers to evolving set shared beliefs, values, } \\
\text { attitudes and logical processes which provides } \\
\text { cognitive maps for people within a given societal } \\
\text { group to perceive, think, reason, act, react and } \\
\text { interact }\end{array}$ & Shapes behaviors \\
\hline $\begin{array}{l}\text { Edgar Schein } \\
(2004)\end{array}$ & $\begin{array}{l}\text { "A pattern of shared basic assumptions that was } \\
\text { learned by a group as it solved its problems of } \\
\text { external adaptation and internal integration, that } \\
\text { has worked well enough to be considered valid and, } \\
\text { therefore, to be taught to new members as the } \\
\text { correct way you perceive, think, and feel in relation } \\
\text { to those problems"(Schein, 2004, p. 17). }\end{array}$ & $\begin{array}{l}\text { A pattern of } \\
\text { valuable } \\
\text { transferable } \\
\text { behaviors }\end{array}$ \\
\hline Anthon (2004) & $\begin{array}{l}\text { Is the set of values, beliefs, and understanding shared } \\
\text { by an organization's employees and it ranks among } \\
\text { an organization's most powerful }\end{array}$ & $\begin{array}{l}\text { Shared } \\
\text { system }\end{array}$ \\
\hline Taylor (2004) & $\begin{array}{l}\text { Refers to what is created from the messages that are } \\
\text { received about how people are expected to behave in } \\
\text { the organization }\end{array}$ & Context \\
\hline Wagner (2005) & $\begin{array}{l}\text { An informal, shared way of perceiving life and } \\
\text { membership in the organization that binds members } \\
\text { together and influences what they think about } \\
\text { themselves and their work }\end{array}$ & Shapes behaviors \\
\hline $\begin{array}{l}\text { Modaff, Butler, } \\
\& \quad \text { DeWine } \\
(2011)\end{array}$ & $\begin{array}{l}\text { Organizational culture can be viewed as a root } \\
\text { metaphor assuming what the organization is; culture } \\
\text { is a sum of personnel experiences viewed differently } \\
\text { by organization members, created through } \\
\text { communication and symbols }\end{array}$ & $\begin{array}{l}\text { Collective } \\
\text { system }\end{array}$ \\
\hline $\begin{array}{l}\text { Brown, Melian, } \\
\text { Solow, } \\
\text { Chheng\& } \\
\text { Parker, } 2015\end{array}$ & $\begin{array}{l}\text { Organizational culture is like a filter, all that happens } \\
\text { in an organization passes through it. }\end{array}$ & $\begin{array}{l}\text { Foundation of an } \\
\text { organizational } \\
\text { sensemaking }\end{array}$ \\
\hline $\begin{array}{l}\text { Kinicki \& Mel } \\
\text { (2016) }\end{array}$ & $\begin{array}{l}\text { A set of shared believes that can be learned and has } \\
\text { an influence on people behaviors and impacts results } \\
\text { at multiple levels. }\end{array}$ & $\begin{array}{l}\text { Org. culture is } \\
\text { shared, } \\
\text { transferrable, and } \\
\text { has an impact. }\end{array}$ \\
\hline $\begin{array}{l}\text { Groysberg, Lee, } \\
\text { Price \& Cheng, } \\
(2018)\end{array}$ & $\begin{array}{l}\text { Organizational culture is an effect of the collective } \\
\text { and common believes, behaviors norms, and values } \\
\text { of the people working in an organization. This }\end{array}$ & $\begin{array}{l}\text { Collective } \\
\text { behavioral system }\end{array}$ \\
\hline
\end{tabular}




\begin{tabular}{|l|l|l|}
\hline & $\begin{array}{l}\text { collective system regulate employees in how they } \\
\text { perform and serve customers }\end{array}$ & \\
\hline
\end{tabular}

In the backdrop of mentioned organizational culture definitions, it can easily be inferred that organizational culture is people-based, people who come together in an organizational context and shape up the overall culture of that organization by their collective and transferrable value systems. This collective behavior and value system define what an organization looks like, how it plans, interacts, and defines values and norms within the context of the organization as well as how an organization wants to be referred to from the outside while interacting with other organizations.

\subsection{Types of Organizational Culture}

Literature has identified several types of organizational culture. The following table has summarized the most prominent types as follows:

Table-3.2 Types/Categories of Organizational Culture

\begin{tabular}{|c|c|}
\hline Author \& Year & Types/Categories of Organizational Culture \\
\hline $\begin{array}{l}\text { Deal \& Kennedy } \\
(1982)\end{array}$ & $\begin{array}{l}\text { i. Work Hard Play Hard: Employees themselves take a few risks; } \\
\text { however, the feedback on how well they are performing is almost } \\
\text { immediate. } \\
\text { ii. Tough Guy Macho Man Culture: This culture contains a world of } \\
\text { individualists who enjoy risk and who get quick feedback on their } \\
\text { decisions. } \\
\text { iii. Process Culture: Slow Feedback, low risk } \\
\text { iv. Bet The Company Culture: decisions are high risk but employees } \\
\text { may wait years before they know whether their actions actually } \\
\text { paid off. }\end{array}$ \\
\hline $\begin{array}{l}\text { Schneider et al, } \\
(1996)\end{array}$ & $\begin{array}{l}\text { i. Control: Certainty and control set the framework for knowledge; } \\
\text { ii. Collaboration: Stakeholders synergies are linked to knowledge } \\
\text { acquisition and use; } \\
\text { iii. Competence: Distinctiveness in terms of competencies forms the } \\
\text { setting for knowledge; } \\
\text { iv. Cultivation: Cultural enrichment is sought through the attainment } \\
\text { of knowledge-based goals }\end{array}$ \\
\hline $\begin{array}{l}\text { Cameron \& Quinn, } \\
\text { (1999) }\end{array}$ & $\begin{array}{l}\text { i. Clan Cultures: characterized by loyalty, commitment, teamwork, } \\
\text { and consensus } \\
\text { ii. Adhocracy Cultures: characterized by entrepreneurialism, } \\
\text { innovation, and freedom; } \\
\text { iii. Hierarchical Cultures: characterized by formalism, structure, and } \\
\text { stability; } \\
\text { iv. Market Cultures: are goal- and results-oriented and competitive }\end{array}$ \\
\hline $\begin{array}{l}\text { Dalkir, } \\
\text { pp.181-182). }\end{array}$ & $\begin{array}{l}\text { i. Communal culture is driven by a sense of belongings, leaders are } \\
\text { generally very inspirational. The negative impact of such } \\
\text { inspirations results in organizational silence } \\
\text { ii. Network culture is all about friendships and family-like } \\
\text { relationships. People help and trust one another. Information is } \\
\text { easily shared. The negative impact is the lack of criticism on poor } \\
\text { performance. } \\
\text { iii. Mercenary Culture enforces strict goals. Goals are placed for quick } \\
\text { achievements. People are expected to act on goals objectively. The } \\
\text { negative side is that people with poor performance are dealt } \\
\text { inhumanely. }\end{array}$ \\
\hline
\end{tabular}




\begin{tabular}{|l|l|}
\hline iv. Fragmented Culture is about committing to individuals first and \\
tasks the second. As a result sense of belonging with an \\
organization. Lack of cooperation is the negative side of such \\
cultures.
\end{tabular}

Each of the organizational culture categories defined in table-3.2 has a measuring tool that defines or divides organizations into the mentioned categories. Jung et al., (2009) concluded that there is no ideal instrument that measures an ideal type of organizational culture, therefore whatever is considered fit for the purpose should be followed.

\subsection{Organizational Culture Dimension}

Organizational culture is a multilayered phenomenon with complex processes therefore literature has identified a number of dimensions for its measurability. A short summary is provided as follows:

Table-3.3 Organization Culture Dimensions

\begin{tabular}{|l|l|}
\hline Author \& Year & Cultural Dimensions \\
\hline $\begin{array}{l}\text { Deal \& Kennedy } \\
(1982)\end{array}$ & $\begin{array}{l}\text { Developed a model based on four different types of organizations. The } \\
\text { crux of the model lies in quick feedback, level of risk that an } \\
\text { organization takes, and rewards system. The dimensions are; work } \\
\text { hard play hard, tough guy macho man culture, process culture, and bet } \\
\text { the company culture. }\end{array}$ \\
\hline $\begin{array}{l}\text { Edgar Schein } \\
(1985-2005)\end{array}$ & $\begin{array}{l}\text { Schein explained culture from an observer view and developed three } \\
\text { cognitive levels; artifacts, values, and tacit assumptions. }\end{array}$ \\
\hline $\begin{array}{l}\text { Daniel Denison's } \\
\text { Model (1990) }\end{array}$ & $\begin{array}{l}\text { Four general dimensions of organization culture i-e. Involvement, } \\
\text { Consistency, Adaptability, and Mission. Each dimension is further } \\
\text { divided into three subcategories; Involvement: Empowerment, Team } \\
\text { Orientation and Capability Development; Consistency: Coordination \& } \\
\text { Integration, Agreement, and Core Values; Adaptability: Creating } \\
\text { Change, Customer Focus, and Organizational Learning; Mission: } \\
\text { Strategic Direction \& Intent, Goals \& Objectives and Vision }\end{array}$ \\
\hline $\begin{array}{l}\text { O'Reilly, Chatman } \\
\text { \& Caldwell (1991) }\end{array}$ & $\begin{array}{l}\text { Seven categories for organization culture; innovation, stability, respect } \\
\text { for people, outcome \& orientation, attention to detail, team orientation, } \\
\text { and aggressiveness. }\end{array}$ \\
\hline $\begin{array}{l}\text { Goffee\& Johns } \\
\text { (2000) }\end{array}$ & $\begin{array}{l}\text { Two dimensions: Sociability: helping one another without expectations } \\
\text { (connected with people orientation), Solidarity: regardless of personal } \\
\text { disputes and conflicts people can still work together (connected to task } \\
\text { orientation). }\end{array}$ \\
\hline $\begin{array}{l}\text { Cameron \& Quinn } \\
\text { (2005) }\end{array}$ & $\begin{array}{l}\text { Based on the competing value framework, four types of cultures as } \\
\text { clan, adhocracy, market, and hierarchy culture. }\end{array}$ \\
\hline
\end{tabular}

\subsection{Organizational Culture Characteristics}

Oxford English Dictionary defines characteristics as a distinguishing feature or quality. Whereas, dimensions refer to the measurability of a construct (Swanson \& Holton III, 2005) i.e. how will a specific characteristic of a construct be measured? Research refers to dimension as a number ray, some concepts require one single number ray e.g. height is measured with the help of a ruler, but others may require multiple number rays e.g. Learning or motivation, etc. (Trochim, 2006). Given the nature of this study, it is pertinent to understand the characteristics of organizational culture as it will help in understanding the challenges and facilitations that it provides to the transfer of knowledge. Following is the list of organizational culture characteristics (qualities/attributes/elements) as explored by a 
number of researchers. The table provides the organizational culture characteristic, description, and source of the description.

Table-3.4 Organizational Culture Characteristics

\begin{tabular}{|c|c|c|}
\hline Characteristics & Description & Source \\
\hline $\begin{array}{l}\text { People create an } \\
\text { organizational } \\
\text { culture }\end{array}$ & $\begin{array}{l}\text { Organizational culture is about people, their } \\
\text { personalities, experiences, interactions within the } \\
\text { organization, communication style, and their emotional } \\
\text { and intellectual expressions. Organizational culture is a } \\
\text { psychological contract between the organization and } \\
\text { individuals working within the organization. }\end{array}$ & $\begin{array}{l}\text { - Sackman, (1991) } \\
\text { - Rousseau, (1995) } \\
\text { - Robbins, (2009) }\end{array}$ \\
\hline $\begin{array}{l}\text { Organizational } \\
\text { culture is } \\
\text { collective }\end{array}$ & $\begin{array}{l}\text { Though organizational culture is formed by individuals } \\
\text { it is a shared experience, something common and } \\
\text { collective. }\end{array}$ & $\begin{array}{ll} & \text { Schein, (2010) } \\
\text { - Alvesson\&Sveningsso } \\
\mathrm{n}(2015) \\
\end{array}$ \\
\hline $\begin{array}{l}\text { Organizational } \\
\text { culture is a living } \\
\text { phenomenon }\end{array}$ & $\begin{array}{l}\text { Organizational culture is a living phenomenon through } \\
\text { which people jointly create and recreate the worlds in } \\
\text { which they live within the organization. It can be } \\
\text { transferred and is acquired from old members to new. }\end{array}$ & $\begin{array}{l}\text { - Morgan, (1997) } \\
\text { - Schein, (2010) }\end{array}$ \\
\hline $\begin{array}{l}\text { Organizational } \\
\text { culture } \\
\text { transferred }\end{array}$ & $\begin{array}{l}\text { It learns to solve problems of external adaptation and } \\
\text { internal integration, something that has worked enough } \\
\text { to be considered valid and to be transferred to new } \\
\text { members as organization knowledge. }\end{array}$ & - Schein, (2010) \\
\hline $\begin{array}{l}\text { Organizational } \\
\text { culture is about } \\
\text { behaviors }\end{array}$ & $\begin{array}{l}\text { Since organizational culture is related to people, } \\
\text { therefore, it is a pattern of behaviors involving; means of } \\
\text { cooperation, a sense of direction, and meaning to the } \\
\text { actions of organization members. }\end{array}$ & $\begin{array}{l}\text { - Schein, (2010) } \\
\text { - Warrick, Milliman\& } \\
\text { Ferguson, (2016) }\end{array}$ \\
\hline $\begin{array}{l}\text { Organizational } \\
\text { cultural has } \\
\text { content }\end{array}$ & $\begin{array}{l}\text { Organizational culture is distinguished with certain } \\
\text { content that forms the basic assumptions of working in } \\
\text { an organization. It consists of artifacts, value systems, } \\
\text { standards or rules, and regulations, etc. }\end{array}$ & $\begin{array}{l}\text { - } \text { Morgan, }(1986) \\
\text { - Hofstede, }(1991) \\
\text { - Trice \& Beyer, (1993) } \\
\text { - Schein, }(2010)\end{array}$ \\
\hline $\begin{array}{l}\text { Organizational } \\
\text { culture is } \\
\text { symbolic }\end{array}$ & Organization culture is expressed in symbols & $\begin{array}{ll}\text { - } & \text { Morgan, (1986) } \\
\text { - } & \text { Schein, (1985) }\end{array}$ \\
\hline $\begin{array}{ll}\text { Organizational } & \\
\text { culture } & \text { is } \\
\text { difficult } & \text { to } \\
\text { change } & \end{array}$ & $\begin{array}{l}\text { Since organizational culture is the collective behavioral } \\
\text { expression of members of the organization, it is difficult } \\
\text { to change. Culture change requires people to change } \\
\text { their behaviors. It is often difficult for people to unlearn } \\
\text { their old way of doing things, and to start performing the } \\
\text { new behaviors consistently. Organizational culture has a } \\
\text { durable and more stable character. }\end{array}$ & $\begin{array}{l}\text { - Kilmann, (1985) } \\
\text { - Hope \& Hendry, } \\
(1995)\end{array}$ \\
\hline $\begin{array}{l}\text { Organizational } \\
\text { culture has an } \\
\text { impact }\end{array}$ & $\begin{array}{l}\text { Organizational culture has a more stable and durable } \\
\text { character therefore it impacts a number of processes and } \\
\text { functions in an organization. Empirical research has } \\
\text { proved the importance of culture in enhancing } \\
\text { organizational performance. The impact of } \\
\text { organizational culture on individualsi-e. Employee } \\
\text { morale, commitment, productivity, physical health, and } \\
\text { emotional wellbeing is also known. }\end{array}$ & $\begin{array}{l}\text { - } \text { Cameron \&Ettington, } \\
\text { (1988) } \\
\text { - Denison, (1990) } \\
\text { - Trice \& Beyer, (1993) } \\
\text { - Daft, (2015) }\end{array}$ \\
\hline Overt and covert & Organizational culture is a complex phenomenon. It is & - McDermott \& O'Dell, \\
\hline
\end{tabular}




\begin{tabular}{|c|c|c|}
\hline $\begin{array}{l}\text { organizational } \\
\text { culture }\end{array}$ & $\begin{array}{l}\text { difficult to observe culture as some part of it is overt } \\
\text { while some covert. Schein (1985) described } \\
\text { organizational culture as an iceberg, just the tip is visible } \\
\text { and all the rest invisible. Organizational values, vision, } \\
\text { philosophy, organization structure, etc. are visible } \\
\text { whereas the unspoken set of values, the perception of } \\
\text { good and bad as termed by the members of the } \\
\text { organization are invisible. }\end{array}$ & $\begin{array}{l}\text { (2001) } \\
\text { - Schein, (2010) }\end{array}$ \\
\hline $\begin{array}{ll}\text { Organizational } \\
\text { culture } & \text { is } \\
\text { difficult } & \text { to } \\
\text { measure } & \end{array}$ & $\begin{array}{l}\text { Given the overt and covert nature of organizational } \\
\text { culture, it is difficult to measure organizational culture. } \\
\text { There is no way to determine which organizational } \\
\text { culture dimensions are important in anyone } \\
\text { organization. }\end{array}$ & - Stanford, (2010) \\
\hline
\end{tabular}

4. Transfer of knowledge

\subsection{What is Knowledge?}

Knowledge is a multi-dimensional construct, with enormous connotations and interpretations (Neta\& Pritchard 2009). Being the driver of the modern world, knowledge is anything but easy to grasp and define (Sun \& Scott, 2005; Van den Berg, 2013). Knowledge is becoming a corporate asset like brand identity, customer information, and corporate reputations (Bhatt, 2000). When organizations merge, downsize, or reorganize priceless knowledge is lost or buried under new information, employees who leave take valuable knowledge with them (Smith, 2001).

The term knowledge has been defined in several different ways in literature, there is no consensus on the definition of knowledge (Qvortrup, 2006). For example, Propp (1999, p. 227) defines knowledge as "content + structure of the individual's cognitive system". Content can be viewed as disorganized information, which becomes knowledge when meaning is provided by the cognitive system of the individual. Similarly for Bates (2005) knowledge is giving context to information and integration with other content of understanding.

Table-4.1 provides a summary of knowledge definitions with details of authors as follows:

Table-4.1 Definitions of Knowledge

\begin{tabular}{|l|l|l|}
\hline Author \& year & Definition & Focus \\
\hline Sveiby (1997) & $\begin{array}{l}\text { Knowledge is an intangible resource that } \\
\text { exists within the mind of the individual. }\end{array}$ & $\begin{array}{l}\text { Intangible in nature and } \\
\text { generated by people }\end{array}$ \\
\hline Davenport (1998) & $\begin{array}{l}\text { Knowledge is a fluid mix of framed } \\
\text { experience, value, contextual information, and } \\
\text { expert insights that provides a framework for } \\
\text { evaluating and incorporating new experiences } \\
\text { and information. }\end{array}$ & $\begin{array}{l}\text { The output of experiences } \\
\text { or context }\end{array}$ \\
\hline $\begin{array}{l}\text { Alavi\&Leidner, } \\
\text { (2001) }\end{array}$ & $\begin{array}{l}\text { "Justified personal belief that increases an } \\
\text { individual's capacity to take effective action" }\end{array}$ & Personal believes \\
\hline $\begin{array}{l}\text { Sharratt\&Usoro } \\
(2003)\end{array}$ & $\begin{array}{l}\text { "knowledge is directly related to } \\
\text { understanding and is gained through the } \\
\text { interpretation of information" }\end{array}$ & $\begin{array}{l}\text { Product or output of } \\
\text { experiences }\end{array}$ \\
\hline $\begin{array}{l}\text { Iske\&Boersma, } \\
\text { (2005) }\end{array}$ & $\begin{array}{l}\text { decisions necessary to execute a specific task. } \\
\text { This ability can, therefore, be seen as the } \\
\text { interaction between insights (from the past), } \\
\text { information (the present) and imagination (the } \\
\text { future)" }\end{array}$ & $\begin{array}{l}\text { A person-specific and } \\
\text { output of experience }\end{array}$ \\
\hline
\end{tabular}


Based on the aforementioned definitions it can easily be inferred that knowledge is personspecific and is the output or product of people's experiences.

\subsection{Types of Knowledge}

Drawing on the work of Polanyi $(1962,1967)$, Nonaka (1994) explained two dimensions of knowledge in organizations i-e. Explicit Knowledge and tacit Knowledge. Explicit knowledge can be expressed in numbers and words and is codified (Polanyi, 1967; Nonaka, 1994; Choo, 2006; van den Berg, 2013). These are then easily shared formally and systematically in the form of data, specifications, manuals, etc. (Boone \&Ganeshan, 2008). Essentially, explicit knowledge is knowing about (Connell, Klein, \& Powell, 2003). An example of explicit knowledge is an owner's manual accompanying the purchase of an electronic product. The manual contains the knowledge of the appropriate operation of the product (Alavi\&Leidner 2001).

Tacit knowledge, on the other hand, is knowing how and includes insights, intuition, and hunches which are often built by experience and difficult to formalize and share (Connell, et al., 2003; van den Berg, 2013). Tacit knowledge which comprised of both cognitive and technical elements is sourced in action, experience, and involvement in a specific context (Nonaka, 1994; Alavi\&Leidner, 2001; van den Berg, 2013). The cognitive elements in tacit knowledge refer to an individual's mental model and technical component consists of knowhow, skills, and crafts that apply to specific contexts (Nonaka 1994; Alavi\&Leidner 2001). An example of tacit knowledge is knowledge of the best means of approaching particular customer-using flattery, using a hard sell, using a no-nonsense approach (Alavi\&Leidner 2001).

In the given background, the following characteristics of types of knowledge are summarized: Table-4.2 Characteristics of Types of Knowledge

\begin{tabular}{|c|c|}
\hline Tacit Knowledge & Explicit Knowledge \\
\hline Subjective & Objective \\
\hline $\begin{array}{l}\text { Knowledge of Experience } \\
\text { (Body) }\end{array}$ & $\begin{array}{l}\text { Knowledge of Rationality } \\
\text { (Mind) }\end{array}$ \\
\hline $\begin{array}{l}\text { Simultaneous Knowledge } \\
\text { (Here \& Now) }\end{array}$ & $\begin{array}{l}\text { Sequential Knowledge } \\
\text { (There \& Then) }\end{array}$ \\
\hline $\begin{array}{ll}\begin{array}{l}\text { Analog } \\
\text { (Practice) }\end{array} & \text { Knowledge } \\
\end{array}$ & $\begin{array}{ll}\text { Digital } \\
\text { (Theory) }\end{array}$ \\
\hline
\end{tabular}

Source: Adapted by Nonaka\& Takeuchi (1995, p.61)

\subsection{Knowledge Management (KM)}

Knowledge Management (KM) is a multi-dimensional construct, consisting of several elements (Frank \&Ribeiro, 2014). That's why there is no single definition for KM (Nesheim\&Gressgard, 2014). Knowledge management is a methodology for creating, maintaining, and exploiting all possible opportunities of knowledge that each organization uses in its activities (Choo, 2006; Dalkir, 2011; Evans \& Ali, 2013; Nesheim\&Gressgard, 2014). Liss (1999, p.1) defines KM as "A formal, directed process of determining what information a company has that could benefit others in the company and then devising ways of making easily available". Whereas, Bhatt (2001, p.71) defines KM as a phase-wise process i-e. "A process of knowledge creation, validation, presentation, distribution, and application". The same phase-wise procedural definition of KM is supported by Alavi and Leidner (2001), Watson (2003), Sedera, Gable, and Chan (2004), Nicolas (2004), Brelade and Harman (2007), Dalkir (2011) and Evans and Ali (2013) i-e. KM involves: development of knowledge, distribution of knowledge, retention of knowledge and usage of knowledge. 


\section{i. Development/ Creation of Knowledge}

Knowledge creation is the ability of an organization to develop novel and useful ideas and solutions (Marakas, 1999). Knowledge creation involves activities that range from developing new substances while replacing the existing substance within the organization's tacit and explicit knowledge and to identify external knowledge and previously unnoticed trends so that they can become the part of organization knowledge (Evans \& Ali, 2013). Whereas, Watson (2003) advocates that knowledge creation or development includes: learning, creating, or identifying knowledge.

\section{ii. Distribution / Sharing / Transfer of Knowledge}

Trautman (2014) defines knowledge transfer as a planned movement of the right kind of skills at the right time to keep workers competitive, motivated, and able to implement the organizational strategy. Argote and Ingram (2000, p. 151) define it as "Knowledge transfer in organizations is the process through which, one unit (e.g., group, department, or division) is affected by the experience of another". Knowledge transfer is evident when experience acquired in one unit affects another (Argote, McEvily\& Reagans, 2003). Knowledge transfer is also viewed from the tactical perspective of converting knowledge into working solutions others see it as the ability to move knowledge from one place to another, whether physical as from one office, unit or division to another or mental that is from one person to another (Brelade\& Harman, 2007). To enhance an organization's performance, knowledge must be shared, distributed, or transferred so that it becomes a potential asset (Sedera, Gable \& Chan, 2004; Swap et al, 2001; Peroune, 2007). Knowledge Transfer leads to knowledge creation (Argote, McEvily\& Reagans, 2003) and it's the continuous creation of new knowledge that gives sustained competitive advantage to the firms in the dynamic and constantly changing globalized markets (Argote \& Ingram, 2000; Sun \& Scott, 2005; Rhodes et al., 2008). Organizations can create new knowledge and gain a competitive advantage over other firms by creating an organizational culture that will promote the transfer of knowledge (Alavi\&Leidner, 2001).

iii. Retention/ Knowledge Storaging

According to Argote, McEvily\& Reagans (2003, p. 572), "Knowledge retention involves embedding knowledge in a repository so that it exhibits some persistence over time." Knowledge Storage refers to the verbalization of tacit knowledge into formats such as formulae, manuals or documentation that is clear and available to others (Marwick, 2001; Dalkir, 2011; Evans \& Ali, 2013). Thus Knowledge needs to retain or store for its use and reuse over the period of time again and again (Sedera, Gable \& Chan, 2004).

iv. Usage/Analysis/ Validation of Knowledge

Knowledge needs to be continuously used, valued, validated and updated for its effective use in an organization because with time some part of knowledge may be obsolete that needs to be updated, reconfigured and refined to the existing realities (Lahti \&Beyerlein, 2000; Bhatt 2001; Watson 2003; Sedera, Gable \& Chan, 2004). Thus the knowledge possessed by an organization is an active unit, which changes over time as new knowledge is added and knowledge not in use fades (Dalkir, 2011; Evans \& Ali, 2013). Thus, to survive, firms must sustain their capacity to produce through ongoing assessment, valuation, and development of their knowledge, and to do so they utilize their knowledge, which otherwise deteriorates (Augier \&Vendelù, 1999).

\subsection{Characteristics of Transfer of Knowledge}

Kang, Rhee, and Kang (2010) identified three characteristics of transfer of knowledge based on knowledge-based view and organizational learning as tacitness, difficulty, and the value attached to knowledge. The mentioned characteristics are the characteristics of knowledge since the transfer of knowledge involves knowledge as the content to be transferred therefore 
the characteristics involve the characteristics of knowledge. Thus the characteristics of transfer of knowledge are subject to the nature and type of knowledge to be transferred.

Table-4.3 Characteristics of Transfer of Knowledge

\begin{tabular}{|c|c|c|}
\hline Characteristic & Description & Source \\
\hline $\begin{array}{l}\text { Transfer of } \\
\text { Knowledge is a } \\
\text { Process }\end{array}$ & $\begin{array}{l}\text { A process that includes a sequence of events, } \\
\text { activities, and actions. Thus it is a process } \\
\text { where the holder of knowledge (sender) } \\
\text { transmits knowledge via a certain medium to } \\
\text { the receiver of knowledge. }\end{array}$ & - Argote \& Ingram (2000) \\
\hline $\begin{array}{ll}\text { Transfer } & \text { of } \\
\text { Knowledge } & \text { Is } \\
\text { About People } & \end{array}$ & $\begin{array}{l}\text { ToK requires people, at least two. One } \\
\text { offering, sending, teaching, or showing } \\
\text { knowledge and another to receive, acquire, } \\
\text { learn, or adapt knowledge. }\end{array}$ & $\begin{array}{l}\text { - Lane et al. (2001) } \\
\text { - Goh (2002) }\end{array}$ \\
\hline $\begin{array}{l}\text { Transfer of } \\
\text { knowledge is } \\
\text { About Behaviors }\end{array}$ & $\begin{array}{l}\text { The transfer takes place between and } \\
\text { among people, therefore it is directly related } \\
\text { to behaviors of people e.g. trust, feeling of } \\
\text { obligation to share knowledge, norms that } \\
\text { encourage open exchanges of knowledge } \\
\text { among organization members, sense of group } \\
\text { identity, the perceived reward of sharing } \\
\text { knowledge, willingness to share (reciprocity } \\
\text { and beliefs regarding various individual } \\
\text { competencies and skills, etc. }\end{array}$ & $\begin{array}{l}\text { - Lane et al. (2001) } \\
\text { - Goh (2002) } \\
\text { - Cabrera (2003) } \\
\text { - Szulanski et al. (2004) } \\
\text { - Narteh (2008) } \\
\text { - Tangarajast al. (2015) }\end{array}$ \\
\hline $\begin{array}{l}\text { Transfer of } \\
\text { Knowledge is } \\
\text { About Social } \\
\text { Relationships and } \\
\text { Communication }\end{array}$ & $\begin{array}{l}\text { For knowledge transfer mechanisms to be } \\
\text { effective, close, tight interactions between } \\
\text { individuals, teams, and organizations are } \\
\text { critical in organizations }\end{array}$ & $\begin{array}{l}\text { - Suppiah\& Sandhu (2011) } \\
\text { - Ryan, \& O’Connor (2013) } \\
\text { - Li, Chang, Lin \& Ma } \\
\text { (2014) }\end{array}$ \\
\hline $\begin{array}{l}\text { Transfer of } \\
\text { Knowledge has a } \\
\text { Content }\end{array}$ & $\begin{array}{l}\text { Transfer of knowledge is about transferring } \\
\text { knowledge, thus knowledge is the content of } \\
\text { the process. The process is defined by the } \\
\text { nature and type of knowledge. }\end{array}$ & $\begin{array}{l}\text { - Nonaka and Takeuchi } \\
\text { (1995) } \\
\text { - Boone \&Ganeshan (2008) } \\
\text { - Mikhailovich\&Mustafa } \\
\text { (2011) }\end{array}$ \\
\hline $\begin{array}{lr}\text { Transfer } & \text { Of } \\
\text { Knowledge } & \text { has } \\
\text { an Impact }\end{array}$ & $\begin{array}{l}\text { Transfer of knowledge impacts several } \\
\text { processes, functions, and behaviors in an } \\
\text { organization e.g. strategic alliance }\end{array}$ & $\begin{array}{l}-\mathrm{Li}(2008) \\
-\mathrm{Li}, \quad \text { Chang, Lin \& Ma } \\
(2014)\end{array}$ \\
\hline
\end{tabular}

\section{Organizational Culture and Transfer of Knowledge}

\subsection{Characteristic Relevance}

Organizational culture is a universe comprising of people, their shared assumptions, beliefs, value systems, experiences, customs, and conventional knowledge (Alavi, Kayworth\&Leidner, 2005; Schein, 2010). Therefore, organizational culture is considered as an antecedent to transfer of knowledge as the former provides context and meaning to the later (Cavaliere\& Lombardi, 2015). The characteristics of organizational culture and transfer of knowledge reveal the organizational culture and transfer of knowledge have similar building blocks e.g. both are dependent on people for creation and continuity, both are the result of collective behaviors, both require networking or social ties to originate and flourish and similarly, both are processes that require structures and channels. Similarly, 
organizational culture and transfer of knowledge are difficult to measure especially when tacit knowledge is being transferred or covert culture is being observed.

Sveiby (1997) suggests that knowledge is an intangible resource that exists within the mind of the individual, therefore, it requires a conducive environment for transfer before it is lost with the retirement, death, or layoff of members of an organization. Thus conceptually knowledge is one of the components of organizational culture; created by members of the organization, transferred by them, used, and re-used.

Organizational culture has similar building blocks as that of transfer of knowledge but at the same time organizational culture has an influencing relationship with a transfer of knowledge as well e.g. if a culture is innovative it will support the new idea creation, sharing and implementation, otherwise, transfer of knowledge is difficult to initiate (Cameron \& Quinn, 1999). Transfer of knowledge also influences organizational culture in return e.g. transfer of knowledge enables an organization to generate new ideas for new product development (Tsai, 2001), as it stimulates the combination of existing and newly acquired knowledge and augments a unit's capacity for making novel linkages and associations (Jansen et al., 2005). Similarly, if knowledge is valued by members of the organization they will transfer it more swiftly.

Although organizations can realize remarkable performance benefits by transferring knowledge, successful knowledge transfer can be difficult to achieve (Wijk, Jansen \& Lyles 2008). Strong social identities and in-group partiality, lack of communicational channels and invisibility of embedded organization cultures values, may slow down knowledge sharing across groups and divisions in organizations (Ashforth\&Mael, 1989; Brewer, 1979; Messick\& Mackie, 1989). Management and decision making styles in a given organization culture influence the transfer of knowledge as "Knowledge is someone's ability to make decisions necessary to execute a specific task. This ability can, therefore, be seen as the interaction between insights (from the past), information (the present), and imagination (the future)" (Iske\&Boersma, 2005, p.128). The creation of new knowledge is dependent on the transformation process of tacit and explicit knowledge involving individuals (Nonaka\& Takeuchi, 1995).Organizations can create new knowledge and gain a competitive advantage over other firms by creating an organizational culture that will promote the Transfer of Knowledge (Alavi\&Leidner, 2001).

\subsection{Empirical Relevance}

Literature has proved the influencing relationship between organizational culture and the transfer of knowledge. The literature has not only proved this relationship via qualitative and quantitative methodologies but also through the mixed methodology. For example, Alavi, Kayworth\&Leidner (2005) conducted a study to empirically test the effect of organizational culture on knowledge management (KM) technology, tools, and outcomes, with the help of case study methodology. The conceptual framework of the study, derived from literature, presumed that organizational values shape knowledge management behaviors that eventually affect the knowledge management outcomes. Data was collected through semi-structured telephonic interviews with 20 professional employees at various company locations, white papers written by organizational members, and other papers such as case studies commissioned by the organization but written by others. The study concluded that cultural values influence an organization's approach to KM. The results are in line with the previous literature, however, the significance of the study lies in the fact that it proved that cultural values affect the very choice of technology or tools to be used for km application.

Similarly, "The impact of organizational culture on knowledge management in higher education" was measured by Biloslavo and Prevodnik (2010). The study was conducted in two Slovenian higher education institutions by studying three business faculties, a faculty of 
organizational sciences, a faculty of social sciences, and a faculty of sports. A Questionnaire was used as the only instrument for data collection. The instrument was divided into three sections; 1) organizational culture assessment instrument (OCAI) developed and validated by Cameron \& Quinn (1999). The Pearson correlation analysis showed the only clan and market culture types have a significant correlation with KM processes.

Other empirical studies are divided into three categories as qualitative, quantitative, and mixed methods, details as follows:

Table-5.1 Quantitative Studies in Organizational Culture \& Transfer of Knowledge

\begin{tabular}{|c|c|c|}
\hline Author \& year & $\begin{array}{l}\text { Measurability of } \\
\text { variables }\end{array}$ & Findings \\
\hline Darin A. Ladd (2002) & $\begin{array}{l}\text { Organizational } \\
\frac{\text { Culture: }}{\text { Openness to Change }} \\
\text { /Innovation, Task- } \\
\text { Oriented } \\
\text { Organizational Growth, } \\
\text { Bureaucratic and } \\
\text { Competition/ } \\
\text { Confrontation } \\
\text { TOK: } \\
\text { Relational Channels, } \\
\text { partner Similarity, } \\
\text { Organizational Self- } \\
\text { Knowledge and } \\
\text { Divergence of Interests }\end{array}$ & $\begin{array}{l}\text { - Openness to Change/innovation is } \\
\text { positively related to relational } \\
\text { channels, and organizational self- } \\
\text { knowledge and negatively to a } \\
\text { divergence of interests. } \\
\text { - Task-oriented organizational } \\
\text { growth is positively related to } \\
\text { relational channels, organizational } \\
\text { self-knowledge, and negatively to a } \\
\text { divergence of interest. } \\
\text { - Bureaucratic culture has an } \\
\text { insignificant relationship with all } \\
\text { the four factors that may influence } \\
\text { knowledge transfer. } \\
\text { - Competition/confrontation } \\
\text { demonstrated a negative } \\
\text { relationship to relational channels } \\
\text { and organizational self-knowledge } \\
\text { and a positive relationship to a } \\
\text { divergence of interest. }\end{array}$ \\
\hline $\begin{array}{l}\text { Brian D. Janz and } \\
\text { PattarawanPrasarnphanich } \\
(2003)\end{array}$ & $\begin{array}{l}\text { Knowledge-centered } \\
\text { culture: } \\
\text { Autonomy: } \\
\text { People related, } \\
\text { Planning related and } \\
\text { Process related } \\
\text { Organizational climate: } \\
\text { Risk, Reward, Warmth, } \\
\text { and Support } \\
\text { Cooperative Learning } \\
\text { Process: } \\
\text { Positive } \\
\text { interdependence, } \\
\text { Promote interaction and } \\
\text { Group process } \\
\text { Knowledge } \\
\underline{\text { learning/outcomes }} \\
\text { Work satisfaction: } \\
\text { Job satisfaction and }\end{array}$ & $\begin{array}{l}\text { - The relationship between autonomy } \\
\text { and cooperative learning was } \\
\text { statistically significant } \\
\text { - The relationship between } \\
\text { organizational climate and } \\
\text { cooperative learning was } \\
\text { statistically significant } \\
\text { - The cooperative learning-work } \\
\text { performance relationship and the } \\
\text { cooperative learning-work } \\
\text { satisfaction relationship were } \\
\text { statistically significant }\end{array}$ \\
\hline
\end{tabular}




\begin{tabular}{|c|c|c|}
\hline & $\begin{array}{l}\text { Growth satisfactions } \\
\text { Work Performance: } \\
\text { Efficiency, } \\
\text { Effectiveness, and } \\
\text { Timelines. }\end{array}$ & \\
\hline Hsu and Huang (2005) & $\begin{array}{l}\text { Organizational } \\
\text { Culture: } \\
\text { Sociability } \\
\text { Customer } \\
\text { Empowerment, Focus, and } \\
\text { Lateral Integration } \\
\text { Solidarity } \\
\text { Shared Vision, Team } \\
\text { Orientation and } \\
\text { Adaptability } \\
\text { KT Performance: } \\
\text { The improvement of } \\
\text { Individual Capability, } \\
\text { Organizational } \\
\text { Capability, and Product } \\
\text { \& Service Capability } \\
\text { Organizational } \\
\text { Characteristics: } \\
\text { IT Support, } \\
\text { Organizational } \\
\text { Structure and Task } \\
\text { Interdependence }\end{array}$ & $\begin{array}{l}\text { Sociability factors of organizational } \\
\text { culture directly influence KT, while } \\
\text { solidarity factors indirectly influence } \\
\text { KT activities via structural } \\
\text { complexity and information } \\
\text { technology support. Finally, trust is } \\
\text { the basis of organizational culture and } \\
\text { indirectly affects KT. }\end{array}$ \\
\hline $\begin{array}{l}\text { Ming-Fong Lai and Gwo- } \\
\text { Guang Lee (2007) }\end{array}$ & $\begin{array}{l}\text { Organizational } \\
\text { Culture: } \\
\text { Entrepreneurial, Tasks- } \\
\text { goal-accomplish, } \\
\text { Smooth-running }\end{array}$ & $\begin{array}{l}\text { Enterprises should adopt an } \\
\text { entrepreneurial culture when } \\
\text { establishing knowledge activities. }\end{array}$ \\
\hline $\begin{array}{l}\text { Roberto Biloslavo and } \\
\text { MojcaPrevodnik (2010). }\end{array}$ & 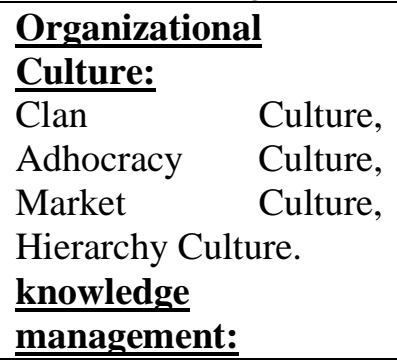 & $\begin{array}{l}\text { - HEI1 confirmed a statistically } \\
\text { significant correlation between } \\
\text { Knowledge storage and market } \\
\text { culture, knowledge transfer and } \\
\text { clan culture, knowledge transfer } \\
\text { and market culture, knowledge } \\
\text { application and clan culture, } \\
\text { knowledge application, and market }\end{array}$ \\
\hline
\end{tabular}




\begin{tabular}{|c|c|c|}
\hline & $\begin{array}{lr}\text { Knowledge } & \text { generation, } \\
\text { Knowledge } & \text { storage, } \\
\text { Knowledge } & \text { transfer, } \\
\text { and } & \text { Knowledge } \\
\text { application } & \end{array}$ & $\begin{array}{l}\text { culture. } \\
\text { - The analysis of HEI2, None of the } \\
\text { types of organizational culture was } \\
\text { in a statistically significant } \\
\text { correlation with any of the } \\
\text { knowledge management processes. }\end{array}$ \\
\hline $\begin{array}{l}\text { Raid. M. Al-Adaileh and } \\
\text { Muawad S. Al-Atawi } \\
\text { (2011) }\end{array}$ & $\begin{array}{l}\text { Organization Culture: } \\
\text { Openness to change, } \\
\text { Innovation, Teamwork, } \\
\text { Morale, Information } \\
\text { flow, involvement, } \\
\text { supervision, Customer } \\
\text { service, Trust and } \\
\text { Reward }\end{array}$ & $\begin{array}{l}\text { - Trust, reward, information flow, } \\
\text { supervision, and innovation were } \\
\text { found to have a statistically } \\
\text { significant impact on knowledge } \\
\text { exchange } \\
\text { - Openness to change, teamwork, } \\
\text { involvement, customer orientation, } \\
\text { and morale were found to the } \\
\text { statistically insignificant impact of } \\
\text { knowledge exchange. } \\
\text { - Stepwise regression proved trust to } \\
\text { be the most important variable } \\
\text { bringing 53\% variation in } \\
\text { knowledge exchange, trust, and } \\
\text { reward explained 56\% variation, } \\
\text { innovation, trust, and reward } \\
\text { explained } 60 \% \text { variation } \\
\text { independent variable. }\end{array}$ \\
\hline $\begin{array}{l}\text { Christina Ling-Hsing } \\
\text { Chang and Tung-Ching } \\
\text { Lin (2015) }\end{array}$ & $\begin{array}{l}\text { Organizational } \\
\text { Culture: } \\
\text { Result Oriented, } \\
\text { Tightly Controlled, } \\
\text { Job-Oriented, Closed } \\
\text { System and } \\
\text { Professional -Oriented } \\
\end{array}$ & $\begin{array}{l}\text { Results- and job-oriented cultures } \\
\text { have positive effects on employee } \\
\text { intention in the KM process (creation, } \\
\text { storage, transfer, and application), } \\
\text { whereas a tightly controlled culture } \\
\text { has negative effects. }\end{array}$ \\
\hline $\begin{array}{l}\text { Sergey } \\
\text { Yakushev, } \\
\text { EmreYildiz, and Carl. F. } \\
\text { Fey (2017) }\end{array}$ & $\begin{array}{l}\text { Organizational } \\
\text { Culture: } \\
\text { Internal Integration and } \\
\text { External Adaption } \\
\text { Knowledge Transfer: } \\
\text { knowledge inflows and } \\
\text { knowledge } \\
\text { implementation }\end{array}$ & $\begin{array}{l}\text { - Dimensions of organizational } \\
\text { culture create the greatest fit when } \\
\text { different degrees of dissimilarity } \\
\text { exists between the HQ and its } \\
\text { subsidiaries. } \\
\text { - The optimal amount of similarity } \\
\text { varied depending on the direction or } \\
\text { stage of knowledge. } \\
\text { - High degrees of distance between } \\
\text { HQs and subsidiaries ipsative all } \\
\text { knowledge transfer outcomes. } \\
\text { - A moderate degree of differences in } \\
\text { the organizational culture between } \\
\text { the HQ and a subsidiary is more } \\
\text { conducive to knowledge transfer. }\end{array}$ \\
\hline
\end{tabular}




\begin{tabular}{|c|c|c|}
\hline $\begin{array}{l}\text { Yihui Wei and Stefano } \\
\text { Miraglia (2017). }\end{array}$ & $\begin{array}{l}\text { Organizational } \\
\text { culture: } \\
\text { Artifacts, Norms, and } \\
\text { Shared Beliefs } \\
\text { Knowledge Transfer: } \\
\text { Knowledge reservoirs }\end{array}$ & $\begin{array}{l}\text { - The systematic management and } \\
\text { transfer of knowledge made a } \\
\text { significant contribution to project } \\
\text { performance and helped expand and } \\
\text { leverage its knowledge reservoirs. } \\
\text { - When knowledge was reused } \\
\text { effectively, many project-related } \\
\text { problems and pitfalls could be } \\
\text { avoided, resulting in a reduction in } \\
\text { reworks waste and costs. } \\
\text { - Artifacts played an important role } \\
\text { in enhancing and encouraging } \\
\text { knowledge transfer practices. } \\
\text { - Certain shared beliefs prompted the } \\
\text { staff to be selective in their } \\
\text { knowledge transfer initiatives. }\end{array}$ \\
\hline $\begin{array}{l}\text { Mohammad Habibur } \\
\text { Rahman, Immanuel } \\
\text { AzaadMoonesar, } \\
\text { MdMunir Hossain and } \\
\text { MdZahidul Islam (2018). }\end{array}$ & $\begin{array}{l}\text { Organizational } \\
\text { Culture: } \\
\text { Trust, Communication } \\
\text { between Employees, } \\
\text { Reward, Leadership, } \\
\text { Learning, and and } \\
\text { Development. }\end{array}$ & $\begin{array}{l}\text { - The effect of communication } \\
\text { between employees, reward, and } \\
\text { trust as significant predictors of } \\
\text { knowledge transfer. } \\
\text { - Socialization plays a moderating } \\
\text { role in all the hypothesized } \\
\text { relationships except between } \\
\text { reward and transfer of knowledge. } \\
\text { - The impact of socialization on the } \\
\text { relationship between } \\
\text { communication, trust, and } \\
\text { knowledge transfer holds true in the } \\
\text { current context where employees } \\
\text { showed differences in their degree } \\
\text { of socialization and its effect on the } \\
\text { corresponding dependent variable. }\end{array}$ \\
\hline
\end{tabular}

Table-5.2 Qualitative Studies in Organizational Culture \& Transfer of Knowledge

\begin{tabular}{|c|c|c|}
\hline Author \& Year & Variable dimensions & Findings \\
\hline $\begin{array}{l}\text { David W. De } \\
\text { Long and Liam } \\
\text { Fahey, (2000) }\end{array}$ & $\begin{array}{l}\text { Organizational } \\
\text { Culture: } \\
\text { Practices, Norms, and } \\
\text { Values } \\
\text { Knowledge: } \\
\text { Human knowledge, } \\
\text { Social knowledge, and } \\
\text { Structured knowledge }\end{array}$ & $\begin{array}{l}\text { - Culture and particularly subcultures-shape } \\
\text { assumptions about what knowledge is and } \\
\text { which knowledge is worth managing. } \\
\text { - Culture defines the relationships between } \\
\text { individual and organizational knowledge, } \\
\text { determining who is expected to control } \\
\text { specific knowledge, as well as who must } \\
\text { share it and who can hoard it. } \\
\text { - Culture creates the context for social } \\
\text { interaction that determines how knowledge } \\
\text { will be used in particular situations. } \\
\text { - Culture shapes the processes by which new } \\
\text { knowledge-with its accompanying } \\
\text { uncertainties-is created, legitimated, and }\end{array}$ \\
\hline
\end{tabular}




\begin{tabular}{|c|c|c|}
\hline & & distributed in organizations. \\
\hline $\begin{array}{l}\text { Richard } \\
\text { Mcdermott and } \\
\text { Carla O'Dell } \\
(2001)\end{array}$ & $\begin{array}{l}\frac{\text { Organizational }}{\text { Culture: }} \\
\text { Visible } \\
\text { organization valture: } \\
\text { vision, philosophy, } \\
\text { organizational structure, } \\
\text { and famous stories that } \\
\text { could be heard in the } \\
\text { corridors of the } \\
\text { company's time and over } \\
\text { again. } \\
\text { Invisible culture: } \\
\text { The unspoken set of } \\
\text { values, the perception of } \\
\text { good and bad as termed } \\
\text { by the members of the } \\
\text { organization }\end{array}$ & $\begin{array}{l}\text { Visible Culture: } \\
\text { - There is a visible link between knowledge } \\
\text { sharing and problem-solving practices of } \\
\text { organizations } \\
\text { - The approaches and tools used by } \\
\text { organizations to support their knowledge } \\
\text { sharing tend to match the overall } \\
\text { organizational style } \\
\text { - Organizational reward system both } \\
\text { monetary and non-monetary support } \\
\text { knowledge sharing. } \\
\text { Invisible Culture: } \\
\text { - Knowledge sharing is linked with the pre- } \\
\text { existing core values of the organization, } \\
\text { - Knowledge sharing networks are built on } \\
\text { existing networks among people. }\end{array}$ \\
\hline $\begin{array}{l}\text { Maryam Alavi, } \\
\text { Timothy R. } \\
\text { Kayworth and } \\
\text { Dorothy E. } \\
\text { Leidner (2005) }\end{array}$ & $\begin{array}{lr}\text { Organizational culture: } \\
\text { Values, } \\
\text { assumptions, } B \text { Basic } \\
\text { Artifacts }\end{array}$ & $\begin{array}{l}\text { - Organizational member's values affect the } \\
\text { ways in which they used km technology. } \\
\text { - The members who valued collaboration } \\
\text { demonstrated the use of communities for } \\
\text { more informal, unstructured sharing of tacit } \\
\text { knowledge wherein the absence of } \\
\text { collaboration values the same communities } \\
\text { were used for organizational explicit } \\
\text { problem solutions. } \\
\text { - Informants who embraced the organizational } \\
\text { value of innovation used intellectual capital } \\
\text { teams for developing and accumulating } \\
\text { intellectual capital whereas those who } \\
\text { valued collaboration used the technology for } \\
\text { networking building through emails and } \\
\text { chatting. } \\
\text { - Groups with different values using km tools } \\
\text { for different purpose experienced diverse km } \\
\text { outcomes. }\end{array}$ \\
\hline
\end{tabular}

Table-5.3 Mixed Method Studies in Organizational Culture \& Transfer of Knowledge

\begin{tabular}{|c|c|c|}
\hline Author \& Year & Variable dimensions & Findings \\
\hline $\begin{array}{l}\text { Al-Alawi, } \\
\text { Marzooqi, and } \\
\text { Mohammed } \\
(2007)\end{array}$ & $\begin{array}{l}\text { Organizational Culture: } \\
\text { Trust, communication, } \\
\text { information systems, rewards, } \\
\text { and organization structure }\end{array}$ & $\begin{array}{l}\text { Trust, communication, information } \\
\text { systems, rewards, and organization } \\
\text { structure are positively related to } \\
\text { knowledge transfer. }\end{array}$ \\
\hline
\end{tabular}

Based on the aforementioned tables (table 5.1, 5.2, and 5.3) following key factors and types of organization culture that affect the transfer of knowledge process in an organization are inferred: 
Table-5.4 Summary of Influencing Factors and Types of Org. Culture

\begin{tabular}{|c|c|}
\hline $\begin{array}{l}\text { Organization Factors } \\
\text { Transfer of Knowledge }\end{array}$ & Types of Org. Culture and ToK \\
\hline $\begin{array}{l}\text { - Communication between org. members } \\
\text { - Existing networks among people } \\
\text { - Information flow } \\
\text { - Information systems } \\
\text { - Interpersonal trust } \\
\text { - Involvement } \\
\text { - Language similarity } \\
\text { - Members autonomy } \\
\text { - Morale } \\
\text { - Openness to change /innovation } \\
\text { - Organizational member's values } \\
\text { - Organizational reward system both } \\
\text { - } \text { Ononetary and non-monetary } \\
\text { - Pre-existing core values of the } \\
\text { organization, pronizational management style } \\
\text { - Problem-solving } \\
\text { organizations } \\
\text { - Senior management support } \\
\text { - Teamwork } \\
\text { - Willingness to share (reciprocate) }\end{array}$ & $\begin{array}{l}\text { - Clan \& Market support transfer of } \\
\text { knowledge (ToK) } \\
\text { - Clan \& Market culture support knowledge } \\
\text { application } \\
\text { - Market Culture support knowledge storage } \\
\text { - Sociability culture (customer focus, } \\
\text { empowerment, lateral integration) directly } \\
\text { influence ToK } \\
\text { - Solidarity culture (shared vision, team } \\
\text { orientation, adaptability) indirectly } \\
\text { influence ToK } \\
\text { - Entrepreneurial culture directly influences } \\
\text { ToK }\end{array}$ \\
\hline
\end{tabular}

\subsection{Knowledge-Based Organizational Cultures}

Knowledge-centered cultures are known to support the transfer of knowledge (Ferreira Peralta \& Francisca Saldanha, 2014), several studies have identified the characteristics of knowledgebased cultures or knowledge-centered cultures (e.g. De Long, 1997; Wiig, 1997; Davenport \&Prusak, 1998; Cohen, 1998; Pfeffer\& Sutton, 2000; Alavi\&Leidner, 2001; Janz\&Prasarnphanich, 2003; Smith \&Mckeen, 2003). De Long (1997) considered the importance of knowledge in an organization and the norms and values attributed to the use of internal and external knowledge as the most important characteristic of a knowledge-based culture. Organizations that consider the knowledge and learning important and value the use of knowledge at the workplace are considered as knowledge-based cultures. De Long (1997) was of the opinion that sub-cultures within the organization conceives or deals knowledge differently, few consider it as an object to be used as a part of a process, others recognize and favor knowledge as a product of social interaction. The author stated that organizational cultures not only define and value knowledge but also decides what kind of knowledge should be kept inside the organization for creating core competencies and what should be transferred outside the organization for strategic advantages. Similarly, De Long advocated that its culture that decides the distribution of knowledge within and among organizations.

Wiig (1997) described four areas that are focused on knowledge-based cultures. Firstly, such cultures have a top-down monitoring governance strategy for managing knowledge management activities that include incentives for knowledge sharing, identification of knowledge assets, restructuring plans (if required). Secondly, knowledge-based cultures have a knowledge-based staff development strategy focusing on the creation and maintenance of knowledge infrastructure. The strategy includes lessons learned programs, development of professional resource pool, and implementation of knowledge base plans. Thirdly, such 
cultures have an operational knowledge management strategy that focuses on managerial responsibilities, training and development plans, research and development, acquisition, innovation, and transformation of knowledge. Lastly, knowledge-based cultures have knowledge leverage strategies that focus on the introduction of best practices for knowledge management, a collaboration that yields productive use of knowledge assets.

Contrary to Wiig (1997), Bollinger and Smith (2001), were of the opinion that instead of management focus, knowledge management activities should be an HR function i-e. initiated and implemented by the human resource department. The authors supported a meaningful role in the HR department in knowledge-based cultures. Bollinger and Smith (2001) supported the reward and compensation systems based on knowledge sharing and nurture. They suggested that training and development should be led by the sole aim of educating employees about the use of knowledge. In knowledge-based cultures, line supervisors are trained and empowered to promote knowledge sharing. Jobs are designed as teams with administrative autonomy, to take advantage of individual know-how. The leadership of knowledge-based cultures values knowledge sharing, retaining people, loyalty, and commitment towards the organization.

Davenport and Prusak (1998) supported the idea of reward management systems based on knowledge sharing, encouragement of risk-taking, and innovative ideas implementation in knowledge-based cultures. Cohen (1998) supported Nonaka and Takeuchi (1995) and advocated socialization and interaction opportunities provisions as a pre-requisite for knowledge sharing in knowledge-based cultures. The authors supported face-to-face relationships, cooperative and collaborative interactions among individuals.

Pfeffer and Sutton (2000) were of the opinion that there is a gap between what people know and what people do in an organization, therefore the focus of knowledge-based cultures should be on the actual ability of individuals to turn knowledge into effective action. Alavi and Leidner (2001) supported the same theme and advocated that there may be occasions where organizational members are not only knowledgeable but are also willing to share knowledge yet, they do not act upon it or materialize the intention of sharing. Thus, the actual conversation of knowledge into action and knowledge sharing activities should be included in incentivizing knowledge-based activities.

Aligned with the mentioned literature, Janz and Prasarnphanich (2003) also supported an organizational culture based on risk-taking, support, warmth and rewards, collaborative learnings focusing on positive interdependence, promotive interactions, and group processes, autonomy related to people, planning and process as characteristics of the knowledge-based cultures.

Smith and Mckeen (2003) identified four categories of factors i-e. Social, organizational, managerial, and technical that assist in instilling a knowledge-based culture. The socialization category focuses on orientation and socialization of new employees, job rotation policies, team-based structures, and the provision of an interactive, informal environment in an organization. The organizational category focuses on incentives and rewards, governance and accountability structures, the flow of information and tracking, and integration of knowledge resources. Whereas, managerial factors include continuous communication about the use and importance of knowledge by leaders and management that is shown via training programs, job designs and incentives, and rewards strategies. Lastly, the technical category includes the introduction of well-designed, user-friendly technological interventions that complement the social, organizational, and managerial categories mentioned before.

Based on the discussion of the knowledge-centered/based culture, characteristics of knowledge-based cultures are summarized and adapted as follows: 
Table-5.5 Characteristics of Knowledge-Based Cultures

\begin{tabular}{|c|c|c|}
\hline $\begin{array}{l}\text { Intervention } \\
\text { Level }\end{array}$ & $\begin{array}{l}\text { Knowledge-Based Strategies and } \\
\text { Activities }\end{array}$ & Source \\
\hline \multirow{5}{*}{$\begin{array}{l}\text { Organizational } \\
\text { Level }\end{array}$} & $\begin{array}{l}\text { Risk-taking and innovative ideas } \\
\text { supportive leadership }\end{array}$ & \multirow{5}{*}{$\begin{array}{l}\text { - Wiig (1997) } \\
\text { - Smith and Mckeen (2003) }\end{array}$} \\
\hline & $\begin{array}{l}\text { Top-down knowledge monitoring } \\
\text { and governance strategy }\end{array}$ & \\
\hline & $\begin{array}{l}\text { Knowledge leverage strategy based } \\
\text { on collaboration and cooperation } \\
\text { (within and outside the } \\
\text { organization) }\end{array}$ & \\
\hline & $\begin{array}{l}\text { Reward and Incentives Strategy } \\
\text { based on knowledge sharing and } \\
\text { new knowledge product and } \\
\text { processes development }\end{array}$ & \\
\hline & $\begin{array}{l}\text { A well-designed and a user-friendly } \\
\text { central database for knowledge } \\
\text { tracking and integration }\end{array}$ & \\
\hline \multirow{4}{*}{$\begin{array}{l}\text { Managerial } \\
\text { Level }\end{array}$} & $\begin{array}{l}\text { Knowledge management based } \\
\text { orientation and socialization policy }\end{array}$ & \multirow{4}{*}{$\begin{array}{l}\text { - Wiig (1997) } \\
\text { - Davenport and Prusak } \\
\text { (1998) } \\
\text { - Pfeffer and Sutton (2000) } \\
\text { - Bollinger and Smith (2001) } \\
\text { - Alavi and Leidner (2001) } \\
\text { - Janz and Prasarnphanich } \\
\text { (2003) } \\
\text { - Smith and Mckeen (2003) }\end{array}$} \\
\hline & $\begin{array}{l}\begin{array}{l}\text { Autonomous } \\
\text { designs }\end{array} \\
\end{array}$ & \\
\hline & $\begin{array}{l}\text { Knowledge-based staff development } \\
\text { policy }\end{array}$ & \\
\hline & $\begin{array}{l}\text { Promotive interaction opportunities } \\
\text { provisions }\end{array}$ & \\
\hline
\end{tabular}

The study considers an organizational culture that is knowledge-based if, at the organizational level, the leadership of the organization supports and emphasizes risk-taking and innovation for new idea development and transference. The organization has a top-down knowledge monitoring and governance strategy, knowledge leverage strategy that promotes and supports collaboration (via networking) and cooperation for creating and transferring knowledge, a rewards and incentives strategy driven by knowledge transfer and new knowledge products and processes development and lastly the organization has a centralized database for tracking and integrating knowledge. At the managerial level, the organization has an orientation and socialization policy based on knowledge management, team-based jobs are designed and incentivized, knowledge-based staff training and development are designed and implemented and interaction opportunities are provided within and outside the organization. 


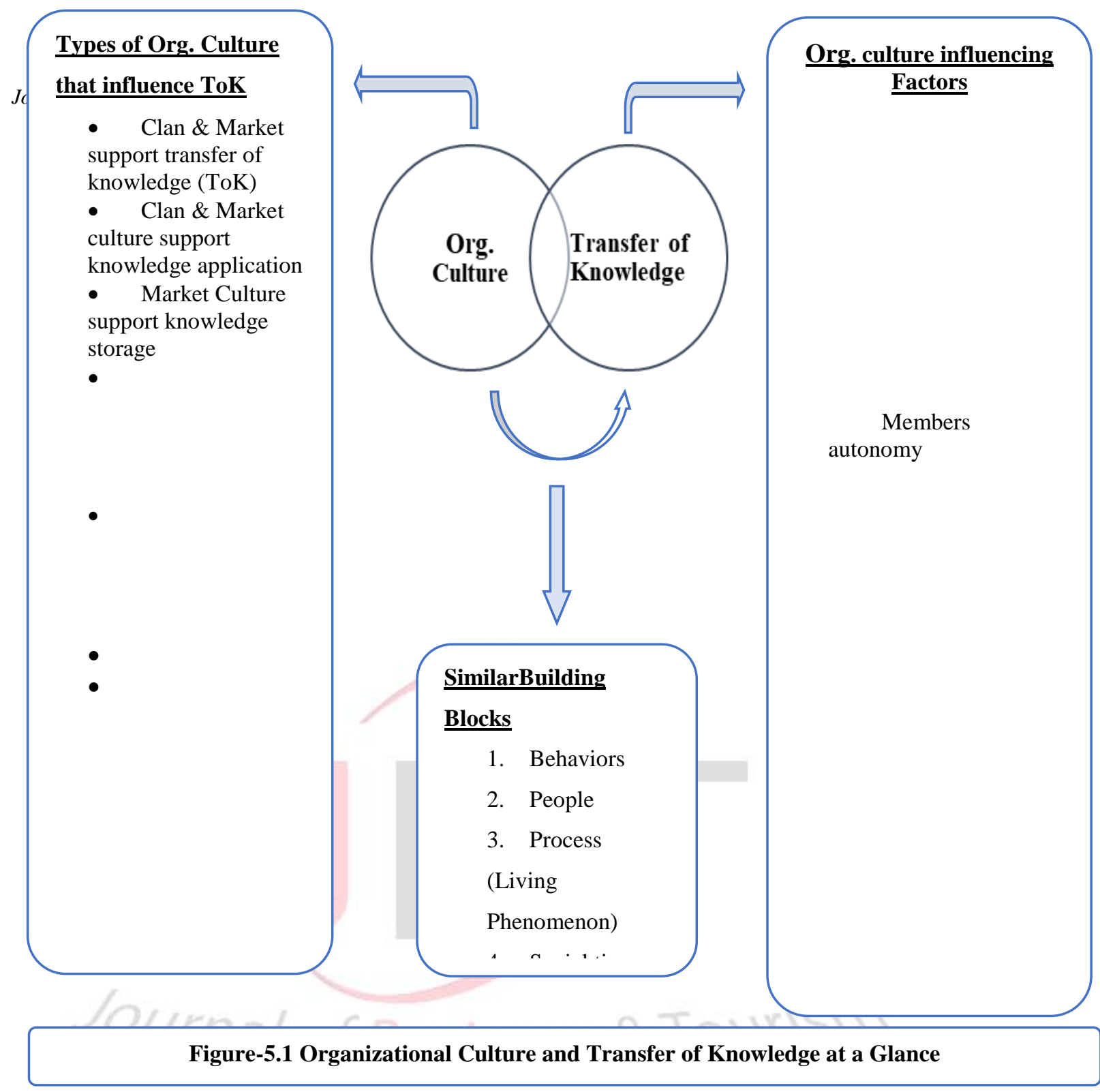

\section{Measurement Instruments and Critique \\ 6.1 Organizational Culture}

Of the papers reviewed for this study, diverse methodologies and research designs can be identified among the various instruments measuring organizational culture. Some instruments adopt a typological approach, which classifies organizational cultures into types, while others adopt a dimensional approach, which describesculture according to its position on various continuous variables (Fletcher \& Jones 1992). Most papers adopting a typological approach have used ipsative measures that include 4, 5, and 6 statement versions. Respondents are usually asked to distribute a set number of points (usually 10 or 100) across the given statements. While those adopting the dimensional approach have used simple Likert scales in order for respondents to signify their agreement with predetermined statements. The items usually range anywhere from 13 to 135 and the range for grading answers on such scales ranges from 3 to 10 . 
Table-6.1 Categorization of various instruments

\begin{tabular}{|c|c|c|}
\hline Approach & Instrument & Authors \\
\hline \multirow{4}{*}{ Typological } & Competing Values Framework & Cameron and Freeman, 1991 \\
\hline & $\begin{array}{l}\text { Harrison's Organizational Ideology } \\
\text { Ouestionnaire }\end{array}$ & Harrison, 1975 \\
\hline & $\begin{array}{l}\text { Quality Improvement Implementation } \\
\text { Survey }\end{array}$ & Shortell et al. 2000 \\
\hline & $\begin{array}{l}\text { Organizational } \\
\text { Instrument }\end{array}$ & Cameron and Quinn, 1999 \\
\hline \multirow{7}{*}{ Dimensional } & Organizational Culture Inventory & Cooke and Lafferty, 1987 \\
\hline & Practice Culture Questionnaire & Stevenson, 2000 \\
\hline & Mackenzie's Culture Questionnaire & MacKenzie, 1995 \\
\hline & Survey of Organizational Culture & $\begin{array}{l}\text { Tucker, McCoy, and Evans, } \\
1990\end{array}$ \\
\hline & Corporate Culture Questionnaire & $\begin{array}{l}\text { Walker, Symon, and Davies, } \\
1996\end{array}$ \\
\hline & Organizational Culture Questionnaire & Hofstede et al. 1990 \\
\hline & Organizational Culture Survey & $\begin{array}{l}\text { Glaser, Zamanou, } \\
\text { Hacker, } 1987\end{array}$ \\
\hline
\end{tabular}

Apart from the quantitative approach, researchers have also employed qualitative approaches to measure organizational culture. The assumed advantage of the qualitative approach is its ability to analyze structures through patterns that are displayed by individual behaviors (Morey \& Morey 1994). Various methods used to identify these patterns are interviews, participant observation, and document analysis (Ott 1989; Morey \& Morey 1994). These approaches allow for a detailed examination of underlying values, beliefs, and assumptions resulting in identifying a rich account of an organization's cultural complexity and dynamics. As such qualitative approaches score relatively high on adaptiveness, flexibility and depth (Tucker, et al. 1990).

Although both approaches have their respective advantages, they are not without their shortcomings. Most of the quantitative instruments examine employee opinions and perceptions regarding their working environment, however only a few, for example, the Competing Values Framework and the Organizational Culture Inventory, attempt to examine the beliefs and values that inform those views. These instruments usually fail to address the unspoken assumptions that direct individual attitudes and behavior. Finally, quantitative instruments greatly vary in the degree of their use in empirical studies, the extent to which their validity and reliability have been established, and the approach used to evaluate their scientific properties. Similarly, qualitative measures, due to their immersed and in-depth nature are very time-consuming, both in gathering and the analysis of data, and are often very costly (Hofstede 2001; Sackmann 2001). They also require the researcher to be sensitive to the subtleties and complexities of life which makes qualitative instruments very difficult to design.

\subsection{Transfer of Knowledge}

To date, there are no specific instruments that measure the transfer of knowledge, because KT is heavily impacted by the types of knowledge. Especially tacit knowledge can be exceptionally difficult to measure as it is embedded in the individual mind such as ideas, skills, and experience. From the literature review, the transfer of knowledge has been measured in various ways. Argote and Ingram, (2000) measured KT from the changes on the recipient side; (i) changes in their performance (ii) the induced changes of the recipient's 
knowledge-base (iii) changes in cumulative knowledge that resides in various repositories. KT is also measured by the process and outcome dimensions. The outcome dimension measures transfer of knowledge from the financial and non-financial criteria. The financial criteria measures KT by the stakeholder's equity, cost reduction, number of patents or intellectual property owned (e.g. Perez-Nordtvedt et al., 2008; Lichtenthaler, 2010) and for non-financial criteria, some researchers have measured KT from the amount of successful KT engagements during any period of time (Li \& Hsieh, 2009), slight changes in the learning-bydoing knowledge level (Cha et al., 2008) and the frequency of contact with knowledge source (Kang et al., 2010) The process dimension usually divide the KT process into various stages; Initiation, Implementation, Ramp-up and Integration (Szulanski, 2000); Motivation, Match, Implementation and Retentive (Kwan \& Cheung, 2006); Search and Transfer (Hansen, 1999) and Socialization, Externalization, Internalization and Combination (Nonaka\& Takeuchi, 1995). A process view of KT allows a critical examination of how difficulty evolves over stages of the transfer. It can also provide important insight into the working of various organizational arrangements to transfer knowledge, communicate managerial interventions and help design and implement mechanisms that support effective transfer of knowledge.

Researchers have also measured KT from the perspective of learning capabilities or learning performance (i.e. the speed, type, extent, and nature of the "new knowledge learned" (Martinkenaite, 2011). Out of the approaches used to measure the transfer of knowledge, past researchers have predominantly measured KT from the outcome perspectives as it is tangible with detailed supporting data and largely in documented form as compared to process perspectives.

\section{Agenda for Future Research}

\subsection{Research Design and Methodology}

From the literature review, it is quite evident that there is an over-reliance on the crosssectional quantitative methodology being used to explore the organizational culture and transfer of knowledge, with very limited longitudinal research being conducted. Measuring complex phenomena such as organizational culture and knowledge transfer with close-ended questionnaires alone may cause the researcher to not explore the deeper levels of culture, (e.g. values and assumptions) and how tacit knowledge is transferred among individuals since such measures usually arrive only at superficial meanings of constructs (Yauch\&Steudel 2003).

Similarly, there has been a paucity in research conducted on exploring the relationship between organizational culture and transfer of knowledge and the effect of subcultures on the transfer of tacit knowledge. While some research has been conducted on answering said questions, most have heavily relied on quantitative instruments (Ladd, 2002; Rahman, Moonesar, Hossain \& Islam, 2018; Wei \&Miraglia, 2017; Morgulis-Yakushev, Yildiz, \& Fey, 2018). In order to further advance the understanding of the cultural conditions that affect the knowledge transfer process researchers are strongly recommended to employ more qualitative and preferably mix-methodologies in their research designs. A meticulous mix-method approach may reveal distinct nuances to the public face. Qualitative and quantitative approaches may be used in a complementary manner, which may help develop a more comprehensive understanding of the relationship organizational culture and transfer of knowledge might have within the organization. A mix-method approach may also allow the researchers to overcome the fundamental limitations of closed statement questionnaires. Researchers may use qualitative research findings to inform hypotheses that are testable by quantitative methods, and similarly, qualitative research may also be used to further explore the meaning of findings from the quantitative analysis.

Through our review, it is evident that there has been an inordinate amount of focus in prior empirical work on exploring the positive effects of organizational culture on the transfer of 
knowledge. However to the best of our knowledge, no research has ever attempted to examine the negative impact organizational culture might have on the knowledge transfer process, hence for theoretical development, we call upon future researchers to conduct research in this direction.

\section{Conclusion}

This literature review attempts to provide evidence concerning the theoretical relationship between organizational culture and transfer of knowledge in the organizational settings. These constructs have been the area of attraction for scholars and practitioners across many disciplines. This study highlights an obvious research gap in the literature about OC and KT. The current literature focuses mainly on the superficial relationship between OC and KT without delving deeper in order to understand how subcultures/covert cultures affect the transfer of knowledge process (especially tacit knowledge) among the individuals as well as outside the organization. Based on the study, it is quite clear that OC and KT are very important areas for future research. However, the nature and method of such complicated and dynamic processes will greatly vary between different organizations in order for them to adapt to potential challenges. Thus, considerable and exhaustive research needs to be conducted in this direction.

\section{References}

Ajmal, M. M., \&Koskinen, K. U. (2008). "Knowledge transfer in project- based organizations: an organizational culture perspective." Project management journal 39(1): $7-15$.

Al-Adaileh, R. M. \& Al-Atawi M. S. (2011). Organizational culture impact on knowledge exchange: Saudi Telecom context. Journal of Knowledge Management15(2), 212-230.

Al-Alawi, A. I., Al- Marzooqi, N. Y. \& Mohammed, F. Y. (2007). Organizational culture and knowledge sharing, critical success factors. Journal of Knowledge Management 11(2), $22-42$.

Alavi, M. \&Leidner D. E. (2001). Knowledge management and knowledge management systems, Conceptual foundations and research issues. MIS quarterly, 107-136.

Alavi, M., Kayworth, T. R. \&Leidner, D. E. (2005). An empirical examination of the influence of organizational culture on knowledge management practices. Journal of management information systems22(3), 191-224.

Alvesson, M. \&Sveningsson S. (2015). Changing organizational culture, Cultural change work in progress, Routledge.

Argote, L. \& Ingram P. (2000). Knowledge transfer, A basis for competitive advantage in firms. Organizational behavior and human decision processes82(1), 150-169.

Argote, L., McEvily, B. \& Reagans, R. (2003). Managing knowledge in organizations, An integrative framework and review of emerging themes. Management Science49(4), 571582.

Ashforth, B. E. \&Mael F. (1989). Social identity theory and the organization. Academy of management review14(1), 20-39.

Augier, M. \&Vendelu M. T., (1999). Networks, cognition and management of tacit knowledge. Journal of Knowledge Management3(4), 252-261.

Bates, M. J. (2005). Information and knowledge, An evolutionary framework for information science. Information Research, An international electronic journal10(4), n4.

Bhatt, G. D. (2000). Organizing knowledge in the knowledge development cycle. Journal of Knowledge Management4(1), 15-26.

Bhatt, G. D. (2001). Knowledge management in organizations, examining the interaction between technologies, techniques, and people. Journal of Knowledge Management5(1), 68-75. 
Biloslavo, R., \&Prevodnik, M. (2010). Impact of Organizational Culture on Knowledge Management in Higher Education in Cultural Implications of Knowledge Sharing, Management and Transfer, Identifying Competitive Advantage Harorimana, D., Hershey, PA, Information Science Reference, 152-179.

Boone, T. \&Ganeshan R. (2008). Knowledge acquisition and transfer among engineers, Effects of network structure. Managerial and Decision Economics29(5), 459-468.

Brelade, S. \& Harman C. (2007). Understanding the modern knowledge worker. Knowledge Management Review10(3), 24.

Brewer, M. B. (1979). In-group bias in the minimal intergroup situation, A cognitivemotivational analysis. Psychological bulletin86(2), 307.

Brown, D., Melian, V., Solow, M., Cheng, S. \& Parker, K. (2015). Culture and engagement, The naked organization. Global Human Capital Trends, Leading in the New World of Work, 35-41.

Burmeister, A., et al. (2019). "Understanding the Motivational Benefits of knowledge transfer for older and younger workers in age-diverse coworker dyads." Journal of Applied Psychology.

Cabrera, E. (2003). Socio-psychological aspects of knowledge sharing in organizations. Proceedings of the 7th Conference on International Human Resource Management, Limerick.

Cameron, K. S. \&Ettingson D. (1988). The conceptual foundations of organizational culture; Handbook of theory and research, Norwell, Massachusetts, Kluwer.

Cameron, K. S. \& Quinn R. E (1999). An introduction to changing organizational culture. Diagnosing and Changing Organizational Culture, Based on the Competing Values Framework, 1-17.

Cameron, K. S., \& Quinn, R.E., (2005). Diagnosing and Changing Organizational Culture, Based on the Competing Values Framework. San Francisco, USA, Jossey-Bass Inc. Pub.

Cameron, K., and S. Freeman. 1991. "Culture, Congruence, Strength and Type: Relationship to Effectiveness." Research in Organizational Change and Development 5: 23-58.

Cavaliere, V. \& Lombardi S. (2015). Exploring different cultural configurations, how do they affect subsidiaries' knowledge sharing behaviors? Journal of Knowledge Management19(2), 141-163.

Chang, C. L.-h. \& Lin T.-C. (2015). The role of organizational culture in the knowledge management process. Journal of Knowledge Management 19(3), 433-455.

Choo, C. W. (2006). The Knowing Organization, How Organizations Use Information to Construct Meaning, Create Knowledge and Make Decisions, Oxford University Press. New York.

Chua, AChua, L. A., \& Pan, S. L. (2008). Knowledge transfer and organizational learning in IS offshore sourcing. Omega, 36(2), 267-281. doi:10.1016/j.omega.2006.06.008

Cohen, M. P. (1998). Determining sample sizes for surveys with data analyzed by hierarchical linear models. Journal of Official Statistics, 14(3), 267.

Connell, N. A. D., Klein, J. H. \& Powell, P. L. (2003). It's tacit knowledge but not as we know it, redirecting the search for knowledge. Journal of the Operational Research Society54(2), 140-152.

Cooke, R., and J. Lafferty. 1987. Organizational Culture Inventory (OCI). Plymouth, MI:HumanSynergistics.

Cummings, J. N. (2004). Work groups, structural diversity, and knowledge sharing in a global organization. Management science, 50(3), 352-364.

Daft, R. L. (2015). Organization theory and design, Cengage learning. 
Dalkir, K. (2005). Knowledge management in theory and practice. Germany, Burlington, MA, Elsvier Butterworth-Heinemann.

Dalkir, K. (2011). Knowledge management in theory and practice, Cambridge, MA, Massachusetts Institute of Technology.

Davenport, T. H. \& L. Prusak (1998). Working knowledge, How organizations manage what they know, Harvard Business Press.

Davenport, T. H. (1998). Putting the enterprise into the enterprise system. Harvard Business Review76(4).

De Long, D. (1997). Building the knowledge-based organization, How culture drives knowledge behaviors. Centers for Business Innovation-Working Paper, 1-29.

De Long, D. W. \& Fahey L. (2000). Diagnosing cultural barriers to knowledge management. Academy of Management Perspectives 14(4), 113-127.

Deal, T. E. \& Kennedy A. A. (1982). Corporate cultures, Addison Wesley Reading, MA.

Denison, D. R. (1990). Corporate culture and organizational effectiveness, John Wiley \& Sons.

Deshpandé, R. A. \& Farley J. U. (2004). Organizational culture, market orientation, innovativeness, and firm performance, an international research odyssey. International Journal of Research in Marketing21(1), 3-22.

Evans, M. \& Ali N. (2013). Bridging knowledge management life cycle theory and practice. International Conference on Intellectual Capital, Knowledge Management and Organisational Learning. ICICKM 2013-Conference Proceedings.

Ferreira P. C. \& Francisca M. S. (2014). Knowledge-centered culture and knowledge sharing, the moderator role of trust propensity. Journal of Knowledge Management18(3), 538-550.

Fletcher, B. C., \& Jones, F. (1992). Measuring organizational culture: The cultural audit. Managerial Auditing Journal.

Frank, A. G. \&Ribeiro J. L. D. (2014). An integrative model for knowledge transfer between new product development project teams. Knowledge Management Research \& Practice12(2), 215-225.

Frost, P. J., Moore, L. F.Louis, Meryl R. E., Lundberg, C. C. \& Martin, J. E. (1985). Organizational culture, Sage Publications, Inc.

Geertz, C. (1973). The interpretation of cultures, Basic books.

Glaser, S., S. Zamanou, and K. Hacker. 1987. "Measuring and Interpreting Organizational Culture." Management Communication Quarterly 1 (2): 173-98.

Goffee, R. (1996). Understanding family businesses, issues for further research. International Journal of Entrepreneurial Behavior \& Research2(1), 36-48.

Goh, S. C. (2002). Managing effective knowledge transfer, an integrative framework and some practice implications. Journal of Knowledge Management6(1), 23-30.

Groysberg, B., Lee, J., Price, J. \& Cheng, J. (2018). The leader's guide to corporate culture. Harvard Business Review96(1), 44-52.

Gudykunst, W. B., Ting-Toomey, S., \& Chua, E. (1988). Culture and interpersonal communication. Sage Publications, Inc.

Gundykunst, W. T.-T., S B (1988). Culture and Interpersonal Communication, Sage, Beverly Hills.

Hansen, M. T. (1999). The search-transfer problem: The role of weak ties in sharing knowledge across organization subunits. Administrative science quarterly, 44(1), 82-111.

Harrison, R. 1(975). “Diagnosing Organization Ideology." In The 1975 Annual Handbook for Group Facilitators, edited by J. Jones, and J. Pfeiffer, pp. 101-7. La Jolla, CA: University Associates. 
Hill, C. \& Jones, G. (2001). Strategic Management, An Integrated Approach. Houghton Mifflin, Boston, MA.

Hofstede, G. (1991). Organizations and cultures, Software of the mind.McGrawHill, New York.

Hofstede, G., B. Neuijen, D. Ohayv, and G. Sanders. 1990. "Measuring Organizational Cultures: A Qualitative and Quantitative Study across Twenty Cases." Administrative Science Quarterly 35: 286-316.

Hope, V. \& Hendry J. (1995). Corporate cultural change-is it relevant for the organisations of the 1990s? Human Resource Management Journal5(4), 61-73.

Howard, L. W. (1998). Validating the competing values model as a representation of organizational cultures. The international journal of organizational analysis 6(3), 231250.

Hsu, F.-M. \& Huang C.-C. (2005). Determinants of knowledge transfer performance from cultural perspective in high-tech industry. The Ninth Pacific Asia Conference on Information Systems (PACIS), IT and Value Creation, Bangkok, Thailand.

Ilvonen, I., et al. (2019). A Business-Driven Process Model for Knowledge Security Risk Management: Tackling Knowledge Risks While Realizing Business Benefits. Effective Knowledge Management Systems in Modern Society, IGI Global: 308-325.

Iske, P. \&Boersma W. (2005). Connected brains, Question and answer systems for knowledge sharing, concepts, implementation and return on investment. Journal of Knowledge Management9(1), 126-145.

Jansen, J. J. P., Van Den Bosch, F. A. J. \&Volberda, H. W. (2005). Managing potential and realized absorptive capacity, how do organizational antecedents matter? Academy of management journal48(6), 999-1015.

Janz, B. D. \&Prasarnphanich P. (2003). Understanding the antecedents of effective knowledge management, the importance of a knowledge centered culture. Decision sciences34(2), 351-384.

Jung, T., Scott, T., Davies, H. T., Bower, P., Whalley, D., McNally, R. \&Mannion, R. (2009). Instruments for exploring organizational culture, A review of the literature. Public administration review69(6), 1087-1096.

Kang, J., Rhee, M., \& Kang, K. H. (2010). Revisiting knowledge transfer, Effects of knowledge characteristics on organizational effort for knowledge transfer. Expert systems with applications 37(12), 8155-8160.

Kang, J., Rhee, M., \& Kang, K. H. (2010). Revisiting knowledge transfer : Effects of knowledge characteristics on organizational effort for knowledge transfer. Expert Systems with Applications, 37(12), 1-6. doi:10.1016/j.eswa.2010.05.072

Kilmann, R. H. (1985). 'Five steps for closing culture gaps', in Kilmann, R. H., Saxton, M., Serpa, R. (Eds). Gaining Control of the Corporate Culture, (p. 351-369). Jossey-Bass, San Francisco.

Kinicki, A. \& Mel F., (2016). Organization Behavior: Practical, Problem-Solving Approach (Singapore: McGraw-Hill Education).

Kroeber, A. L. \&Kluckhohn C. (1952). Culture, A critical review of concepts and definitions. Papers. Peabody Museum of Archaeology \& Ethnology, Harvard University.

Kwan, M. M., \& Cheung, P. K. (2006). The knowledge transfer process: From field studies to technology development. Journal of Database Management (JDM), 17(1), 16-32.

Ladd, D. A. (2002). An Investigation of Environmental Factors that Influence Knowledge Transfer in the Air Force.

Lahti, R. K. \&Beyerlein M. M. (2000). Knowledge Transfer and Management Consulting, A Look at The Firm. Business Horizons43(1), 65-74. 
Lai, M.-F. \& Lee G.-G. (2007). Relationships of organizational culture toward knowledge activities. Business process management journal13(2), 306-322.

Lane, P. J., Salk, J. E. \& Lyles, M. A. (2001). Absorptive capacity, learning, and performance in international joint ventures. Strategic management journal22(12), 1139-1161.

Li C.Y., and Hsieh C.T. (2009). The impact of knowledge stickiness on knowledge transfer implementation, internalization, and satisfaction for multinational corporations. International Journal of Information Management, 29(6), 425-435.

$\mathrm{Li}$, A. (2008). What affects organizational performance? The linking of learning and knowledge management. Industrial Management \& Data Systems108(9), 1234-1254

Li, J. H., Chang, X. R., Lin, L. \& Ma, L. Y. (2014). Meta-analytic comparison on the influencing factors of knowledge transfer in different cultural contexts. Journal of Knowledge Management18(2), 278-306.

Lichtenthaler U. (2010). Outward knowledge transfer: the impact of project-based organization on performance. Industrial and Corporate Change Advance, 1-35. doi:10.1093/icc/dtq041

Liss, K. (1999). Do we know how to do that? Understanding knowledge management. Harvard Management Update4(12), 1-4.

MacKenzie, S. 1995. "Surveying the Organizational Culture in an NHS Trust." Journal of Management in Medicine 9 (6): 69-77.

Marakas, G. M. (1999). Decision support systems in the twenty-first century. Prentice-Hall, Englewood Cliffs, NJ.

Martinkenaite, I. (2011). Antecedents and consequences of inter- organizational knowledge transfer. Baltic Journal of Management.

Marwick, A. D. (2001). Knowledge management technology. IBM systems journal40(4), 814830.

McDermott, R. \& Odell C. (2001). Overcoming cultural barriers to sharing knowledge. Journal of Knowledge Management5(1), 76-85.

Mesmer-Magnus, J. R., \&DeChurch, L. A. (2009). Information sharing and team performance: A meta-analysis. Journal of applied psychology, 94(2), 535.

Messick, D. M. \& Mackie D. M. (1989). Intergroup relations. Annual review of psychology 40(1), 45-81.

Michailova, S. \&Mustaffa Z. (2011). Subsidiary knowledge flows in multinational corporations, Research accomplishments, gaps, and opportunities. Journal of world business 47(3), 383-396.

Modaff, D. P., Butler, J. A., \& DeWine, S. (2011). Organizational communication, Foundations, challenges, and misunderstandings, Boston, MA, Allyn \& Bacon.

Morey, N. C. and R. V. Morey (1994). "Organizational Culture: The Management Approach." National Association for the Practice of Anthropology Bulletin 14(1): 17-26.

Morgan, G. (1986). Images of Organisation. Beverly Hills, CA, Sage Publications.

Morgan, G. (1997). Images of organization. Thousands Oaks. CA, Sage Publications.

Morgulis-Yakushev, S., Yildiz, H. E. \& Fey, C. F. (2018). When same is (not) the aim, A treatise on organizational cultural fit and knowledge transfer. Journal of world business53(2), 151-163.

Nahapiet, J., \&Ghoshal, S. (1998). Social capital, intellectual capital, and the organizational advantage. Academy of management review, 23(2), 242-266.

Narteh, B. (2008). Knowledge transfer in developed-developing country interfirm collaborations, a conceptual framework. Journal of Knowledge Management12(1), 78-91.

Nesheim, T. \&Gressgård L. J. (2014). Knowledge sharing in a complex organization, Antecedents and safety effects. Safety science 62, 28-36. 
Neta, R. \& Pritchard D. (2009). Arguing about knowledge, Routledge.

Nicolas, R. (2004). Knowledge management impacts on decision making process. Journal of Knowledge Management8(1), 20-31.

Nonaka, I. \& Takeuchi H. (1995). The knowledge-creating company, How Japanese companies create the dynamics of innovation, Oxford university press.

Nonaka, I. (1994). A dynamic theory of organizational knowledge creation. Organization science 5(1), 14-37.

O'Reilly, C. A., Chatman, J. \& Caldwell, D. F. (1991). People and organizational culture, A profile comparison approach to assessing person-organization fit. Academy of management journal34(3), 487-516.

Ott, J. 1989. The Organizational Culture Perspective. Chicago: Dorsey

Ouchi, W. G. (1981). The Z organization. Classics of organization theory, 451-460.

Pérez-Nordtvedt, L., Kedia, B. L., Datta, D. K., \& Rasheed, A. A. (2008). Effectiveness and Effciency of Cross-Border Knowledge Transfer: An Empirical Examination. Journal of Management Studies, 45(4), 714-744.

Peroune, D. L. (2007). Tacit knowledge in the workplace, the facilitating role of peer relationships. Journal of European Industrial Training.

Peters, T. \& Waterman R. H. (1982). In search of excellence. Harper and Row, New York.

Pettigrew, A. M. (1979). On Studying Organizational Cultures Andrew M. Pettigrew. Administrative science quarterly24(4).

Pfeffer, J., \& Sutton, R. I. (2000). The knowing-doing gap, How smart companies turn knowledge into action. Harvard business press.

Polanyi, M. (1962). Tacit knowing, It's bearing on some problems of philosophy. Reviews of modern physics34(4), 601.

Polanyi, M. (1967). The tacit dimension. Anchor. Garden City, NY.

Propp, K. M. (1999). Collective information processing in groups. The handbook of group communication theory and research (225-250). Thousand Oaks, CA, Sage.

Qvortrup, L. (2006). Knowledge, Education and Learning-E-learning in the knowledge society.

Rahman, M. H., Moonesar, I. A., Hossain, M. M. \& Islam, M. Z. (2018). Influence of organizational culture on knowledge transfer, E vidence from the $\mathrm{G}$ overnment of $\mathrm{D}$ ubai. Journal of Public Affairs18(1), e1696.

Rhodes, J., Hung, R., Lok, P., Ya-Hui Lien, B., \& Wu, C. M. (2008). Factors influencing organizational knowledge transfer, implication for corporate performance. Journal of Knowledge Management12(3), 84-100.

Robbins, S. P. (2009). Organizational Behavior, Pearson Education South Africa.

Rousseau, D. (1995). Psychological contracts in organizations, Understanding written and unwritten agreements, Sage publications.

Ryan, S. \& O'Connor R. V. (2013). Acquiring and sharing tacit knowledge in software development teams, An empirical study. Information and Software Technology55(9), 1614-1624.

Sackmann, S. (2001). Cultural Complexity in Organizations: the Value and Limitations of Qualitative Methodology and Approaches. The International Handbook of Organizational Culture and Climate. C. L. Cooper, S. Cartwright and C. Earley. Chichester, John Wiley \& Sons: 143-163.

Sackmann, S. A. (1991). Cultural knowledge in organizations, Exploring the collective mind, Sage Publications, Inc.

Schein, E. H. (2004). Organizational culture and leadership. San Francisco, CA, Jossey-Bass. Schein, E. H. (2010). Organizational culture and leadership, John Wiley \& Sons. 
Schneider, B., Brief, A. P. \&Guzzo, R. A. (1996). Creating a climate and culture for sustainable organizational change. Organizational Dynamics24(4), 7-19.

Schneider, S. (1997). Managing Across CultureHemel Hempstead, Prentice Hall Europe.

Sedera, D., Gable, G. G. \& Chan, T. (2004). Knowledge management as an antecedent of enterprise system success, Association for Information Systems.

Sharratt, M. \&Usoro A. (2003). Understanding knowledge-sharing in online communities of practice. Electronic Journal on Knowledge Management1(2), 187-196.

Shortell, S. M., R. H. Jones, A. W. Rademaker, R. R. Gillies, D. S. Dranove, E. F. X Hughes, P. P. Budetti, K. S. E. Reynolds, and C. Huanf. 2000. "Assessing the Impact of Total Quality Management and Organizational Culture on Multiple Outcomes of Care for Coronary Artery Bypass Graft Surgery Patients.' Medical Care 38 (2): 207-17.

Slocum, J. W. (1995). Group culture. Blackwell encyclopedic dictionary of organizational behavior, 124-125.

Smith, E. A. (2001). The role of tacit and explicit knowledge in the workplace. Journal of Knowledge Management5(4), 311-321.

Smith, H. A., \&McKeen, J. D. (2003). Knowledge management in organizations, the state of current practice. In Handbook on knowledge management (pp. 395-410). Springer, Berlin, Heidelberg.

Stadler, R. (2019). Knowledge management in event and festival organisations: Challenges and future directions. A Research Agenda for Event Management, Edward Elgar Publishing.

Stanford, N. (2010). Corporate culture, Getting it right. John Wiley \& Sons.

Stevenson, K. 2000. "Are Your Practices Resistant to Changing Their Clinical Culture?" Primary Care Report 2 (5): 19-20.

Sullivan, H. (2001). Modernisation, Democratisation and Ccommunity Governance. Local Government Studies 27(3), 1-24.

Sun, P. \& Scott, J. L. (2005). An investigation of barriers to knowledge transfer. Journal of Knowledge Management $9(2), 75-90$.

Suppiah, V. \& Sandhu S. M. (2011). Organisational culture's influence on tacit knowledgesharing behaviour. Journal of Knowledge Management15(3), 462-477.

Sveiby, K. E. (1997). The new organizational wealth, Managing \& measuring knowledgebased assets. Berrett-Koehler Publishers.

Swanson, R. A. \& Holton E. F. (2005). Research in organizations, Foundations and methods in inquiry.Berrett-Koehler Publishers.

Swap, W., Leonard, D., Shields, M. \& Abrams, L. (2001). Using mentoring and storytelling to transfer knowledge in the workplace. Journal of management information systems 18(1), 95-114.

Swartz, M. J. \& Jordan D. K. (1980). Culture, The anthropological perspective, John Wiley $\&$ Sons.

Szulanski, G., Cappetta, R. \& Jensen, R.J. (2004). When and how trustworthiness matters, Knowledge transfer and the moderating effect of causal ambiguity. Organization science 15(5), 600-613.

Tangaraja, G., Rasdi, R. M., Ismail, M. \&Samah, B. A. (2015). Fostering knowledge sharing behaviour among public sector managers, a proposed model for the Malaysian public service. Journal of Knowledge Management 19(1), 121-140.

Taylor C., (2004). The Power of Culture, Turning the Soft Stuff into Business Advantage. Australia, McGraw Hill.

Trautman, S. (2014). Practices to Embed Knowledge Transfer into Your Business Culture.

Trice, H. M. \& Beyer J. M. (1993). The cultures of work organizations, Prentice-Hall, Inc. 
Trochim, W. M. (2006). The Research measures knowledge base. Cincinnati, Atomic Dog Publishing.

Trompenaars, F. (1993). Riding the waves of change, Understanding cultural diversity in business. London, Nicholas Brealey.

Tsai, W. (2001). Knowledge transfer in intraorganizational networks, Effects of network position and absorptive capacity on business unit innovation and performance. Academy of management journal44(5), 996-1004.

Tucker, R., W. McCoy, and Evans. 1990. "Can Questionnaires Objectively Assess Organizational Culture?', Journal of Managerial Psychology 5 (4): 4-11.

Tucker, R., W. McCoy, and Evans. 1990. "Can Questionnaires Objectively Assess Organizational Culture?', Journal of Managerial Psychology 5 (4): 4-11.

Uttal, B. (1983). The corporate culture vultures. Fortune108(8), 66-72.

Van den Berg, H. A. (2013). Three shapes of organisational knowledge. Journal of Knowledge Management 17(2), 159-174.

Walker, H., G. Symon, and B. Davies. 1996. "Assessing Organizational Culture: A Comparison of Methods.' International Journal of Selection and Assessment 4 (7): 96105.

Warrick, D. D., Milliman, J. F. \& Ferguson, J. M. (2016). Building high performance cultures. Organizational Dynamics 1(45), 64-70.

Watson, I. (2003). Applying knowledge management, techniques for building corporate memories, Morgan Kaufmann.

Wei, Y. \&Miraglia S. (2017). Organizational culture and knowledge transfer in project-based organizations, Theoretical insights from a Chinese construction firm. International Journal of Project Management35(4), 571-585.

Wiig, K. M. (1997). Knowledge management, Where did it come from and where will it go? Expert systems with applications 13(1), 1-14.

Wijk, R. V., Jansen, J. J. P. \& Lyles, M. A. (2008). Inter-and intra-organizational knowledge transfer, a meta analytic review and assessment of its antecedents and consequences. Journal of management studies 45(4), 830-853.

Yauch, C. A., \&Steudel, H. J. (2003). Complementary use of qualitative and quantitative cultural assessment methods. Organizational research methods, 6(4), 465-481. 